\title{
Geotoxic Materials in the Surface Environment
}

\author{
John J. Koranda \\ Jerry J. Cohen \\ Craig F. Smith \\ Frank J. Ciminesi
} MASTER

\author{
UCRI,- -53215
}

DE82 005855

December 7, 1981 


\title{
Geotoxic Materials in the Surface Environment
}

\author{
John J. Koranda \\ Lawrence Livermore National Laboratory \\ Jerry J. Cohen \\ Craig F. Smith \\ Science Applications, Inc. \\ Frank J. Ciminesi \\ California State Lniversity at Hayward
}

Manuscript date: December 7, 1981 


\section{CONTENTS}

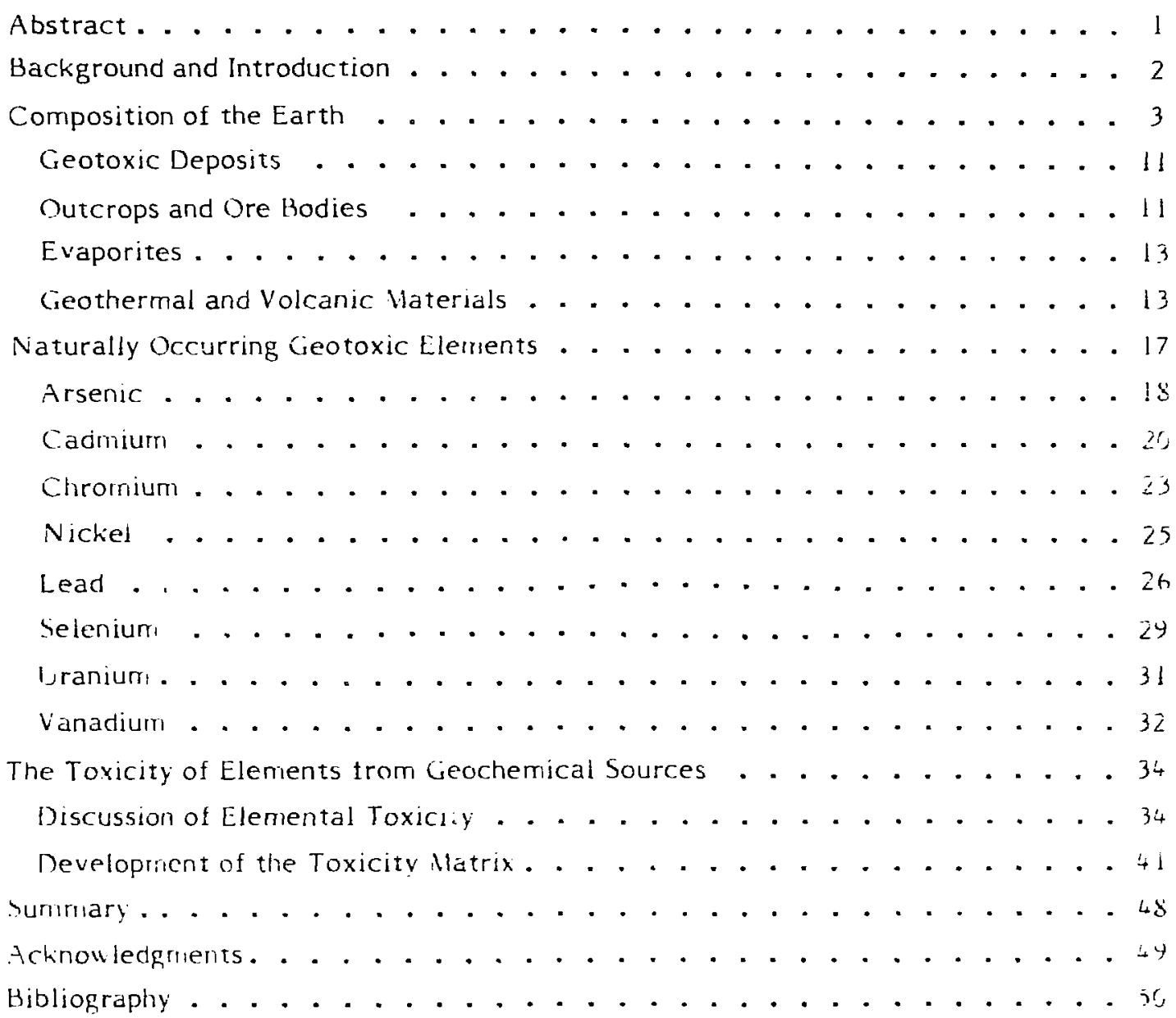




\title{
GEOTOXIC MATERIALS IN THE SIJRFACE ENVIRONMENT
}

\author{
ABSTRACT
}

Knowledge of thie natural distribution of toxic substances in the surface geviogical environment provides a useful baseline for the assessment and eventual use of geological media for the storage and disposal of hazardous wares. Here we develop data sources and provide insights into the existence and behavior of geotoxic substances in the natural environment.

The composition of the earth is described from the literature on geochemistry and the abundance of major and trace constituents of the silicate crust is described and discussed as well.

The relationship of naturaliy occurring deposits of potentially hazardous geological materials to the general problem of hazardous waste disposal in geological media is discussed. Three basic types of geotoxic deposits are identified: ore bodies, evaporites, and geothermal and volcanic features. The use of phosphorite ore bodies for terilizer manufacturing is discussed further as a case in point. The agricultural utilization of phosphatic rocks constitutes an important potential source of geotoxic materials in the human food chàn.

We review the toxicology and natural occurrence of several recognized geotoxic elements including arsenic, cadmium, chromium, nickel, lead, selenium, uranium, and vanaulum. The behavior of these elements in the environment and in biological systemis is examined.

The properties of these eight toxic elements are summarized and presented in a toxicity matrix. The toxicity matrix identifies each of the elenients in terms of average crustal abundance, average soil concentration, drinking water standards, irrigation water standards, daily human intake, aquatic toxicity, phytotoxicity, mammalian toxicity, human toxicity, and bioaccumulation factors for fish. Fish are the major aquatic environment contribution to the human diet and bioaccunulation in aquatic ecosystemis has been demionstrated to be an irsportant factor in the cycling of elements in aquatic ecosystems. The toxicity matrix is used as a first approximation to rank the geotoxizity of elements for the purpose of tocusing future efforts. The ranking from highest to lowest toxicity with respect to the toxicity parameters being discussed is as follows: arsenic, cadmium, lead, selenium, chromium, vanadium, nickel, and uranium. Other rankings may be obtained with the use of different toxicity parameters. 


\section{BACKGROUND AND INTRODUCTION}

The safe disposal of radioactive and other hazardous wastes is a problem of increasing concern. Determination of acceptably safe miethods for disposal of radioactive wastes has proven to be a serious constraint in the development of nuclear power. The predominant methods that have been utilized in the past and proposed for future application involve underground burial of radioactive and cherrical toxic wastes. Such burial is intended to minimize environmental and biological inipacts by reducing or eliminating the potential release and transport of such niaterials within the biosphere.

The presence of potentially hazardous levels of naturally occurring geological material: has been recognized in many parts of the world and the effects of many of these deposits have been studied. Although the cherrical form of the naturally occurring geological chemical and the hazardous or radioactive waste chemical may olfer, there are sonie useful and constructive comparisons that can be nade to place the problemi of waste disposal in the proper perspective. One salient difference is that the radioactive spiscies have a finite, albeit often long physical half-lite, whereas the naturally occurrmg geologica! chemical maintains its toxicity forever unless chemica! weathering, biological transformation, or transport removes it from the accessible enviroment or changes its chemical form.

Recognizing that incorporation of toxic material in the Larth's crust does not present a new or unique phenomenon, we have undertaken a study of geotoxicity impacts to provide useful insights to the problems that result from unoerground burial of hazardous wastes. The geotoxicity study involves the characterization and evaluation of the potential environmental and biological impacts of toxic material incorporated in the Earth's crust by either man or nature.

Applications for geotoxicity information can be found in the following areas.

- Placement of problems invoiving underground burlal of radioactive and other hazardous wastes in to a reasonable perspective.

- Improved understanding of the movenient, transport, and environmental impacts of radioactive and chemically toxic materials buried underground. Insights to the hydrogeologic transport and biological imipact of radionuclides can be gainec by comparison with their stable eleirient analogs in many cases.

- Evaluation of the incremental impact resulting from burial of hazardous waste in identified areas of high existing geotoxicity.

- Improved understanding of the role of geochemistry in health and disease. 
With these applications in mind, we summarize our initial efforts toward a study of geotoxicity and develop a preliminary, systematic afproach toward the understanding of geotoxic phenomena and their relationship to human health. Such study will identify the most useful and productive areas for continued investigation.

\section{COMPOSITION OF THE EARTH}

The chemical composition of the Earth's surface has assumed greater importance in our present technology ior several reasons. The requirement for previously exotic and rare trace elements by industry has promoted geochemical exploration for such elements as cadmium, germanium, antimony, and son of the rare earths. Numerous other uses of elements typically occurring in the Earth's crust in the trace element range have arisen from the semiconductor industry and from the manufacture of rubber, plastics, and elastomers.

Knowledge of the surficial geology is also required for the assessment and eventual use of geological media for storage and disposal of hazardous wastes. Armed with the detailed information on the natural distribution and biological consequences of toxic substances in the surface environment, one can realistically determine the effects of repositories of hazardous materials in various portions of the geosphere. Natural deposits of toxic elements have, in a sense, supplied us with many test cases of the behavior o1 toxic materials in geological media.

The structure of the Earth is generally believed to consist of a neterogeneous silicate crust, a silicate mantle similar to ultrabasic igneous rocks, and an iron-rickel core. The Mohorovicic discontinuity (Moho) separates the crustal region from tine mantle and is characterized by a rapid increase in the velocity of seismic waves at approxintately 5 to $30 \mathrm{kml}$. The Moho has been described as either a chemical or a physical interface.

"Most of the geochemical data we have to utilize for this discussion is related to the silicate crust in which oxygen, silicon, and aluminum are the most abundant elements. The crust of the Earth has a mean depth of $17 \mathrm{~km}$, an average density of $2.8 \mathrm{gm} / \mathrm{cm}^{3}$, and comprises only $0.4 \%$ of the Earth's total mass. It is composed primarily of igneous and metamorphic rocks by volumie $(95 \%)$, with unly $4 \%$ shales, $0.75 \%$ sandstones, and $0.25 \%$ as limestone. Where sedimentary and metamorphic racks occur as a thin veneer, they are usually underlain by ipneous basement rocks. 
The major oxide compounds that comprise the continental crustal rocks were determined by Poldervaart (1955) and more recently by Ronov and Yaroshevsky (1969), whose data are shown in Table 1. It is obvious from Table 1 that silicon and aluminum compounds dominate the materials of the Earth's crust although locally, carbonates may occur over large areas. The elements that comprise the major portion of the Earth's crust are given as weight and atom percentages in Table 2 (Mason, 1966).

TABLE 1. Major elemental compounds in the continental Earth's crust (Ronov and Yaroshevsky, 1969).

\section{Weight percent}

\begin{tabular}{|c|c|c|c|c|c|c|c|c|c|c|}
\hline $\mathrm{SiO}_{2}$ & $\mathrm{Al}_{2} \mathrm{O}_{3}$ & $\mathrm{CaO}$ & $\mathrm{FeO}$ & $\mathrm{Fe}_{2} \mathrm{O}_{3}$ & $\mathrm{MgO}$ & $\mathrm{Na}_{2} \mathrm{O}$ & $\mathrm{K}_{2} \mathrm{O}$ & $\mathrm{TiO}_{2}$ & $\mathrm{P}_{2} \mathrm{O}_{5}$ & Mno \\
\hline 61.9 & 15.6 & 5.7 & 3.9 & 2.6 & 3.1 & 3.1 & 2.9 & 0.8 & 0.3 & 0.1 \\
\hline
\end{tabular}

TABLE 2. Major elements in the Earth's crust (Mason, 1966).

\begin{tabular}{lcc}
\hline Element & $\begin{array}{c}\text { Weight percent } \\
\left(\mathrm{g} / \text { ton } \times 10^{4}\right)\end{array}$ & $\begin{array}{c}\text { A tom } \\
\text { percent }\end{array}$ \\
\hline Oxygen & 46.6 & 62.55 \\
Silicon & 27.72 & 21.22 \\
Aluminum & 8.13 & 6.47 \\
Iron & 5 & 1.92 \\
Calcium & 3.63 & 1.94 \\
Sodium & 2.83 & 2.64 \\
Potassium & 2.59 & 1.42 \\
Magnesium & 2.09 & 1.84
\end{tabular}


The average weight percentage of a given element in the Earth's crust has been termed a clarke (Mason, 1966). When applied to the concentration of the more rare elements, the clarke of concentration is employed, especially when referring to ore deposits. This term is useful in discussing ore deposits because it compares the average crustal abundance of the element to that which is found in a specific mineral or ore deposit. The concentration clarke for iron required for a commercially extractable ore body is 6 , which means that the concentrations need be six times the average crustal abundance of $5 \%$ for extractable ore status. Un the other hand, manganese has a clarke of 0.1 and a concentration clarke of 350 is required for ore body status. Wluch of the $10^{6}$ to $10^{7}$ tons of manganese produced in the world per year is obtained from seawater, however, where it is present at $0.002 \mathrm{ppm}$ (Krauskopf, 1967). The extraction technology rather than the concentration clarke is the dominant factor in production in this case.

The abundances of the more widely dispersed or trace elements in average crustal materials (Taylor, 1964); sedimentary rocks, shales, sandstones, and carbonates ( $T$ ' rekian and Wedepohl, 1961); and igneuus rocks (Mason, 1966) are show'n in Table 3.

During recent biogeochemical studies, data on the occurrence of elements in the alluvium that covers the Imperial Valley of California were obtained by neutron activation analysis (Koranda et al., 1980). These data are shown in Table 4 and can be compared to the soil values given in Bowen (1966) shown in Table 5. The Imperial Valley data are derived from 37 samples collected in the northern part of the area within $8 \mathrm{~km}$ of the south shore of the Salton Sea and reflect the composition of the alluvium that has been laid doun in the salton Trough in recent geological time. Colorado Kiver sediments uere deposited in the Imperial V'alley basin as late as 19l0. Physiographically, the data should be considered as soil, but because of the lack of strong morphogenic differentiation in the soil profiles and its relatively recent age, the data are more appropriately considered as geologic materials, namely alluvium.

The composition of soils, which are bioclımatically weathered products of the environment's interaction with parent materials, may differ from the crustal abundance data. Data from Bowen (1966) on soil composition are shown ir Table 5. The leaching and removal of soluble constituents as well as the addition of others in agricultural practices or through other natural or anthropic activities can cause the concentrations in the soil to vary from those occurring in the parent materials. 
TABLE 3. Concentrations of elements in crustal rocks. ${ }^{a}$

\begin{tabular}{|c|c|c|c|c|c|}
\hline \multirow[b]{2}{*}{ Element } & \multicolumn{5}{|c|}{ Parts per million } \\
\hline & $\begin{array}{l}\text { crustal } \\
\text { abundance }\end{array}$ & Granite & Shales & Sandstones & Carbonates \\
\hline Boron & 10 & 2 & 100 & 35 & 20 \\
\hline $\begin{array}{l}\text { Fluorine } \\
\text { Sodium }\end{array}$ & $\begin{array}{r}625 \\
28,300\end{array}$ & $\begin{array}{r}700 \\
24,600\end{array}$ & $\begin{array}{r}740 \\
9,600\end{array}$ & $\begin{array}{r}270 \\
3,300\end{array}$ & $\begin{array}{l}330 \\
400\end{array}$ \\
\hline Magnesium & 20,900 & 2,400 & 15,000 & 7,000 & 47.000 \\
\hline Aluminum & 81,300 & 74,300 & 80,000 & 25,000 & 4,200 \\
\hline Silicon & 277,200 & 339,600 & 73.000 & 368,000 & 24,000 \\
\hline Phosphorus & 1,060 & 390 & 700 & 170 & 400 \\
\hline $\begin{array}{l}\text { Sulphur } \\
\text { Chlorine }\end{array}$ & $\begin{array}{l}260 \\
130\end{array}$ & $\begin{array}{r}175 \\
50\end{array}$ & $\begin{array}{r}2.400 \\
180\end{array}$ & $\begin{array}{r}240 \\
10\end{array}$ & $\begin{array}{r}1.200 \\
150\end{array}$ \\
\hline Calcium & 36,300 & 9.900 & 22,100 & 39,100 & 302,300 \\
\hline Scandium & 22 & 3 & 13 & 1 & 1 \\
\hline Titanium & 4,400 & 1.500 & 4,600 & 1,500 & 400 \\
\hline Vanadium & 135 & 16 & 130 & 20 & 20 \\
\hline Chromium & 100 & 22 & 90 & 35 & 11 \\
\hline Manganese & 950 & 230 & 850 & - & 1.100 \\
\hline Iron & 50,000 & 13,700 & 47,200 & 9,800 & 3,800 \\
\hline Cobalt & 25 & 2.4 & 19 & 0.3 & 0.1 \\
\hline Nickel & 75 & 2 & 68 & 2 & 20 \\
\hline Copper & 55 & 13 & 45 & -- & 4 \\
\hline zinc & 70 & 45 & 95 & 16 & 20 \\
\hline Gallium & 15 & 18 & 19 & 12 & 4 \\
\hline Germanium & 1.5 & 1 & 1.6 & 0.8 & 0.2 \\
\hline Arsenic & 1.8 & 0.8 & 13 & 1 & 1 \\
\hline Selenium & 0.05 & -- & 0.6 & 0.05 & 0.08 \\
\hline Bromine & 2.5 & 0.5 & 4 & 1 & 6.2 \\
\hline Rubidium & 90 & 220 & 140 & 60 & 3 \\
\hline Strontium & 375 & 250 & 300 & 20 & 610 \\
\hline Yttrium & 33 & 13 & 26 & 40 & 30 \\
\hline Zirconium & 165 & 210 & 160 & 220 & 19 \\
\hline Niobium & 20 & 20 & 11 & - & 0.3 \\
\hline Molybdenum & 1.5 & 7 & 2.6 & 0.2 & 0.4 \\
\hline Ruthenium & 0.01 & -- & -- & -- & - \\
\hline Rhodium & 0.005 & - & -- & - & $-\infty$ \\
\hline Palladium & 0.01 & 0.01 & - & -- & - \\
\hline Silver & 0.07 & 0.04 & 0.07 & -- & - \\
\hline Cadmium & 0.2 & 0.06 & 0.3 & -- & 0.03 \\
\hline Indium & 0.1 & 0.03 & 0.1 & - & $\ldots$ \\
\hline $\operatorname{Tin}$ & 2 & 4 & 6 & - & - \\
\hline Antimony & 0.2 & 0.4 & 1.5 & - & 0.2 \\
\hline Tellurium & 0.01 & - & $\cdots$ & $\ldots$ & - \\
\hline lodine & 0.5 & - & 2.2 & 1.7 & 1.2 \\
\hline Cesium & 3 & 1.5 & 5 & $\ldots$ & -- \\
\hline Barium & 415 & 1220 & 580 & -- & 10 \\
\hline Lanthanum & 30 & 120 & 92 & 30 & - \\
\hline
\end{tabular}


TABLE 3. (Continued.)

\begin{tabular}{|c|c|c|c|c|c|}
\hline \multirow[b]{2}{*}{ Element } & \multicolumn{5}{|c|}{ Parts per million } \\
\hline & abundance & Granite & Shales & Sands tones & Carbonates \\
\hline Cerium & 60 & 230 & 59 & 92 & 11.5 \\
\hline Praesodymium & 8.2 & 20 & 5.6 & 8.8 & 1.1 \\
\hline Neodymium & 28 & 55 & 24 & 37 & 4.7 \\
\hline Samarium & 6 & 11 & 6.4 & 10 & 1.3 \\
\hline Europium & 1.2 & 1 & 1 & 1.6 & 0.2 \\
\hline Gadolinium & 5.4 & 5 & 6.4 & 10 & 1.3 \\
\hline Terbium & 0.9 & 1.1 & 1 & 1.6 & 0.2 \\
\hline 1) ysprosiumi & 3 & 2 & 4.6 & 7.2 & 0.9 \\
\hline Holmium & 1.2 & 0.5 & 1.2 & 2 & 0.3 \\
\hline Erbium & 2.8 & 2 & 2.5 & 4 & 0.5 \\
\hline Thuliumi & 0.5 & 0.1 & 0.2 & 0.3 & 0.04 \\
\hline Ytterbiun & 3.4 & 1 & 2.6 & 4 & 0.5 \\
\hline Lutetium & 0.5 & 0.1 & 0.7 & 1.2 & 0.2 \\
\hline Hafnium & 3 & 5.2 & 2.8 & 3.9 & 0.3 \\
\hline Tantalum & 2 & 1.6 & 0.8 & - & - \\
\hline Tungsten & 1.5 & 0.4 & 1.8 & 1.6 & 0.6 \\
\hline Rhenium & 0.001 & 0.0006 & -- & -- & -- \\
\hline Osmiumi & 0.005 & 0.0001 & -- & -- & -- \\
\hline Iridium & 0.001 & 0.006 & -- & -- & -- \\
\hline Platinum & 0.01 & 1.008 & -- & -- & -- \\
\hline Gold & 0.004 & 0.002 & -- & -- & -- \\
\hline Vercury & 0.08 & 0.2 & 0.4 & 0.03 & 0.04 \\
\hline Thallium & 0.5 & 1.3 & 1.4 & 0.8 & -- \\
\hline Lead & 13 & 49 & 20 & 7 & 9 \\
\hline Bismu & 0.2 & 0.1 & -- & -- & -- \\
\hline Thorium। & 7.2 & 52 & 12 & 1.7 & 1.7 \\
\hline Uranium & 1.8 & 3.7 & 3.7 & 0.45 & 2.2 \\
\hline
\end{tabular}

${ }^{a}$ From Taylor (1964); Turekian and Wedepohl (1961); and Mason (1966). 
TABLE 4. Trace elements in surface soils of the Imperial Valley

(Koranda et al., 1980).

\begin{tabular}{|c|c|c|c|c|}
\hline \multirow[b]{2}{*}{ Element } & \multirow{2}{*}{$\begin{array}{l}\text { Frequency }{ }^{\mathrm{a}} \\
\quad(\%)\end{array}$} & \multirow{2}{*}{$\begin{array}{c}\text { Mean } \\
\text { concentration } \\
\text { (ug/g dry weight) }\end{array}$} & \multicolumn{2}{|c|}{ Concentration range } \\
\hline & & & Maximum & Minimum \\
\hline Sodium & 100 & 7,193 & 15,590 & 4,504 \\
\hline Magnesium & 100 & 20,087 & 32,950 & 14,170 \\
\hline Aluminum & 100 & 49,239 & 64,890 & 10,210 \\
\hline Chlorine & 87 & 2,443 & 18,200 & 2 \\
\hline Potassium & 100 & 18,477 & 20,500 & 15,560 \\
\hline Calcium & 100 & 35,340 & 47,309 & 5,430 \\
\hline Scandium & 100 & 9.4 & 10 & 7.2 \\
\hline Titanium & 90 & 3,057 & $4,50 !$ & 101 \\
\hline Vanadium & 87 & 75 & 101 & 30 \\
\hline Chromium & 10 & 49 & 61 & 42 \\
\hline Manganese & 100 & 468 & 540 & 422 \\
\hline Iron & 100 & 26,689 & 30,700 & 20,500 \\
\hline Cobalt & 100 & 10 & 11 & 8 \\
\hline Nickel & 13 & 35 & 42 & 31 \\
\hline Zinc & 100 & 89 & 117 & 68 \\
\hline Gallium & 83 & 19 & 30 & 12 \\
\hline Arsenic & 100 & 9.1 & 16 & 6.3 \\
\hline Rubidium & 100 & 116 & 132 & 92 \\
\hline Strontium & 100 & 258 & 341 & 218 \\
\hline Zirconium & 100 & 134 & 259 & 72 \\
\hline Molybdenum & 93 & 2.5 & 10 & 4.9 \\
\hline Indium & 50 & 1.6 & 12 & 0.1 \\
\hline Antimony & 100 & 0.9 & 1 & 0.7 \\
\hline Cesium & 100 & 6.8 & 8.1 & 4.9 \\
\hline Barium & 100 & 511 & 649 & 437 \\
\hline Lanthanum & 100 & 32 & 37 & 21 \\
\hline Cerium & 100 & 64 & 71 & 56 \\
\hline Neodymium & 100 & 29 & 32 & 25 \\
\hline Europium & 100 & 0.8 & 0.9 & 0.7 \\
\hline Hafnium & 100 & 5.1 & 7.2 & 4.3 \\
\hline Thorium & 100 & 10.3 & 11.6 & 8.8 \\
\hline Uranium & 100 & 2.9 & 3.5 & 2.2 \\
\hline
\end{tabular}

aFrequency of detection in sample series. 
TABLE 5. Average crustal abundance of elements compared to their occurrence in surface soils.

\begin{tabular}{|c|c|c|c|}
\hline \multirow[b]{2}{*}{ Element } & \multicolumn{3}{|c|}{ Parts per million } \\
\hline & Crustal average ${ }^{a}$ & Soil average ${ }^{b}$ & $\begin{array}{l}\text { Range of soil } \\
\text { concentration }\end{array}$ \\
\hline Lithium & 20 & 30 & $7-200$ \\
\hline Beryllium & 2.8 & 6 & $0.1-40$ \\
\hline Boron & 10 & 10 & $2-100$ \\
\hline Carbon & 200 & 20,000 & $--c$ \\
\hline Nitrogen & 20 & 1.000 & $200-2,500$ \\
\hline Oxygen & 466,000 & 49,000 & -- \\
\hline Fluorine & 625 & 200 & $30-300$ \\
\hline Sodium & 28,300 & 6,300 & $75 r_{,-7,500}$ \\
\hline Magnesium & 20,900 & 5,000 & $600-6,000$ \\
\hline Aluminum & 81,300 & 71.000 & $10,000-300,000$ \\
\hline Silicon & 277,200 & 33,000 & $25,000-350,000$ \\
\hline Phosphorus & 1,050 & 650 & -- \\
\hline Sulfur & 260 & 700 & 30.900 \\
\hline Chlorine & 130 & 100 & -- \\
\hline Potassium & 25,900 & 14,000 & $400-30,000$ \\
\hline Calcium & 36,300 & 13,700 & $7,000-500,000$ \\
\hline Scandium & 22 & 7 & $10-25$ \\
\hline Titanium & 4,400 & 5,000 & $1,000-10,000$ \\
\hline Vanadium & 135 & 100 & $2-500$ \\
\hline Chromium & 100 & 100 & $5-3,000$ \\
\hline Manganese & 950 & 850 & $100-400$ \\
\hline Iron & 50,000 & 38,000 & $7,000-550,000$ \\
\hline Cobalt & 20 & 8 & $1-40$ \\
\hline Nickel & 75 & 40 & $10-1,000$ \\
\hline Copper & 55 & 20 & $2-100$ \\
\hline Zinc & 70 & 50 & $10-300$ \\
\hline Gallium & 15 & 30 & $0.4-300$ \\
\hline Germanium & 1.5 & I & $1-50$ \\
\hline Arsenic & 1.8 & 6 & $2-100$ \\
\hline Selenium & 0.05 & 0.2 & $0.01-2$ \\
\hline Bromine & 2.5 & 5 & $1-10$ \\
\hline Rubidium & 90 & 100 & $20-600$ \\
\hline Strontium & 375 & 300 & $50-1,000$ \\
\hline Yttrium & 33 & 50 & $25-\ddot{C} 50$ \\
\hline Zirconium & 165 & 300 & $\theta 0-2,000$ \\
\hline Niobium & 20 & -- & -- \\
\hline Molybdenum & 1.5 & 2 & $0.2-5$ \\
\hline Ruthenium & 0.01 & -- & -- \\
\hline Rhodium & 0.005 & -- & -- \\
\hline
\end{tabular}


TABLE 5. (Continued.)

\begin{tabular}{|c|c|c|c|}
\hline \multirow[b]{2}{*}{ Element } & \multicolumn{3}{|c|}{ Parts per million } \\
\hline & Crustal average & Soil average & $\begin{array}{l}\text { Range of soll } \\
\text { concentration }\end{array}$ \\
\hline Palladium & 0.01 & -- & $=$ \\
\hline $\begin{array}{l}\text { Silver } \\
\text { Cadmium }\end{array}$ & $\begin{array}{l}0.97 \\
0.2\end{array}$ & $\begin{array}{l}0.1 \\
0.06\end{array}$ & $\begin{array}{l}0.01-5 \\
0.01-0.7\end{array}$ \\
\hline Indium & 0.1 & -- & -- \\
\hline Tin & 2 & 10 & $2-200$ \\
\hline Antimony & 0.2 & -- & $2-10$ \\
\hline Tellurium & 0.01 & -- & -- \\
\hline lodine & 0.5 & 5 & -- \\
\hline Cesium & 3 & 6 & $0.3-2.5$ \\
\hline Barium & 425 & 500 & $100-3,000_{j}$ \\
\hline Lanthanum & 30 & 30 & $1-5.000$ \\
\hline Cerium & 60 & 50 & -- \\
\hline Lead & 13 & 10 & $2-100$ \\
\hline Bismuth & 0.2 & -- & -. \\
\hline Thorium & 7.2 & 5 & $5.1-12$ \\
\hline Uranium & 1.8 & 1 & נ. \\
\hline
\end{tabular}

NOTE: Elements from praseodymium to thallium not determined for sols.

${ }^{a}$ From Mason (1966).

${ }^{b}$ From Bowen (1966).

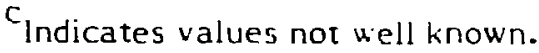


The basic sources of geochenical data describing the composition of the suriare environment are used whenever generic information is required, or when specific data on the actual geological milieu under discussion is lacking. A detalleo assessment justifles the actual measurement of the chemical composition of the medium being considered for waste disposal or for other engineering use. The composition of the Earth's crust may vary widely from the generalized values shown in the tables in the case of ore vodies, salt deposits or evaporites, and geothermal and voicanic features such as hor springs, mud volcanos, fumaroles, and some local outcrops. For example, areas underlain by serpentinite are known for their high mietal content in both the parent materials and the soils derived from the tormation (Soane and Saunder. 1ysy). It is our intent here to relate. these naturally occurring deposits of potential!y iuxic geological matertals to the genera! problem of hazaroous adste orsposal in geological media.

\section{(IEOTOXIL DEPUSITS}

Natuially occurring deposits of toxic substances in geological media are typically three basic types:

(1) outcrops, ore bodies, and undisturbed feological sirata in contact $u$ ith the surface environment ;

(2) evaporites, salt laties, playas: and

(3) geothernal features such as stearm vents, solfataras, furraroles, mud wicanos, and various kinds of volcarnic ejecta.

OI T(RIPS AND IRE HINDIES

Toxic minerals and elentents are often developed m mining cperations producing lead. cadmium, mercury, tron, nanaganese, gold, nickel, and other elentents. 'Yne unique use of ore bodies is the utilization of phosphorites or phosphatic ruck us tertilizer in agriculture. The phusphatic rock is mined, crusned. Washeg with phosphuric acid to rase the phosphorus content to 40 to (in the case of treble super phospliate), and ther. pelletized. The tertilizer is used on crop ilelus, espectally lugh-ytelong rou crops, it rates up to 400 to/acre. Analyses $c$ i the rock ore and me applied fertilizer are snown in Table b. Sne of the major concerns from the stanopomit of human health und food cham relationships in the phospnate fertilizer is cadrilura d $92 \mathrm{pp} / \mathrm{T}$. Which is 460 umes the average crustal abundance (Bouwer and lickloveen, 1973). All ot the elements aiscussec nere occur in phosphatic terializer, uhich constitutes a relatively unevaluated source of 
TABLE 6. Trace elements in phosphate ore and pnosphate fertilizer (Koranda et al., 1980).

\begin{tabular}{|c|c|c|c|}
\hline \multirow[b]{2}{*}{ Elemient } & \multicolumn{3}{|c|}{ Parts per mullion } \\
\hline & $\begin{array}{l}\text { Gay Mine ore } \\
\text { composite. } \\
\text { Idaho }\end{array}$ & $\begin{array}{l}\text { Conda Mine ore } \\
\text { washed composite, } \\
\text { Idaho }\end{array}$ & $\begin{array}{c}\text { Phosphate fertilizer, } \\
\text { Imperiai Valley, } \\
\text { California }\end{array}$ \\
\hline Sodiun & 4.918 & 3.426 & 4,397 \\
\hline Nagnesium & 1,977 & 3,208 & 5,160 \\
\hline Aluminum & 6,778 & 5,594 & 7,136 \\
\hline Potassium & 2,729 & 2,633 & 2,210 \\
\hline Calcium & 27.050 & 26,280 & 14.315 \\
\hline $\begin{array}{l}\text { Scandium } \\
\text { Titanium }\end{array}$ & $\begin{array}{r}2 \\
681\end{array}$ & $\begin{array}{r}3 \\
4,923\end{array}$ & ${ }_{--}^{4.1}$ \\
\hline Vanadium & 857 & 463 & 861 \\
\hline Chromium & 475 & 316 & 461 \\
\hline Manganese & 105 & 68 & 210 \\
\hline Iron & 3,481 & 3,202 & 4,786 \\
\hline Cobalt & 1.5 & 1.9 & 2.7 \\
\hline Nickel & 110 & 92 & 104 \\
\hline Inc & 882 & 629 & 966 \\
\hline Arsenic & 14.9 & 8.2 & 10.8 \\
\hline Seleniurn & 2.7 & 12.1 & 2.8 \\
\hline Rubidium & 10.4 & 9.9 & 13.4 \\
\hline Strontiur: & 949 & 940 & 516 \\
\hline Zirconsumi & 102 & 137 & 50 \\
\hline Molybdenum & 10.5 & 10.1 & 19.6 \\
\hline silver & 4.5 & 6.1 & 1.9 \\
\hline Cadrisum & 81 & 89 & 92 \\
\hline Indium & 4 & -- & - \\
\hline Antimony & 3.5 & 2.3 & 3.3 \\
\hline lodine & 2.5 & 1.3 & -- \\
\hline Chlorine & 49.5 & 136.5 & 40.6 \\
\hline Cesium & 1.1 & 0.8 & 1.1 \\
\hline Barium & 114.1 & 91.6 & 89 \\
\hline Lanthanum & 54.9 & 75.1 & 93.5 \\
\hline Cerium & 21.4 & 32.7 & 35.6 \\
\hline Neodymium & 41.7 & 70.6 & 36.3 \\
\hline Samarium & 6.4 & 10.6 & 6.1 \\
\hline Europium & 1.1 & 1.9 & 1 \\
\hline Terbium & 1.1 & 1.8 & 1 \\
\hline Dysprosium & 7.6 & 14.2 & 7.5 \\
\hline Ytterbium & 5.5 & 9.2 & 7 \\
\hline Lutetium & 1.6 & 2.6 & 2.2 \\
\hline Hafnium & 1.2 & 1.9 & 0.9 \\
\hline Tantalum & 0.2 & 0.2 & -- \\
\hline Thorium & 1.3 & 2.1 & 2.1 \\
\hline Ijranium & 64 & 79.7 & 105.8 \\
\hline
\end{tabular}

a Not detected. 
toxic elements in man's food chan. In the Imperial valley, 140,060 ton of this fertilizer are used per year and $1 \mathrm{t}$ is used widely in Central cialifornia and other parts of the Western 1... S. as well.

\section{EVAPORITES}

Evaporite deposits are derived from the evaporation of marine salt or terrestrial saline waters in salt pans, playas, salinas, lagoons, and relict seas, such as the Salton Sea of southern California (Stewart, 1963). The internal drainage of desert basins in the basin and Range Province of the Hestern I:s. often creates shallow modern evaporite deposits in the playas and ephemeral lakes that occupy the centers of the basıns. The concentrations of salts such as halite, sylvite, and polyhalıte in these areas are toxic to almost all species of plants. Since Lambrian tume, thick and extensive evaporite deposits of marıne origin have been laid down in various regions such as Michıgan, Miontana, and woming. They are found also in Central Europe (Stewart, 1963). Mlodern evaporite deposits are being formed continually in arıd and semiarid clinates, such as those arouno the Niediterranean Sea and the Western U.S. They are often deposited in the rain shadows of high north-south trending mountain chains in the Northern henisphere. Nono Lake in California, the Great Salt Lake in Utah, and the surrounding deposits are examples of contemporary evaporite formation.

Evaporite deposits are dqminated by chlorides, sulfates, carbonates, and borates, which are precipitated in a selatively orderly sequence from the crystallizing salt solution. Carbonates are deposited first. The sequence is never completely ordereo because some factor in the depositional and evaporating environment usually varies and the crystallization process normally does not go to completion. The primary elements and compounds found in evaporites are the same as in seawater, namely, sodium, chlorine, sulphate, magnesium, calcium, potassium, and carbonate in that order of abundance. Trace elements prominent in evaporite deposits are strontium (30 pprn), boron ( $10 \mathrm{ppm}$ ), silicon (8 ppm), and fluorine (4 ppm) (Stewart, 1963).

\section{GEOTHERMAL AND VILCANIC MATERIALS}

Volcanic and geothermal materials may contain rather high concentrations of the toxic elements discussed here, as well as others with toxıc potential at concentrations much higher than typical crustal values. The recent 1980 eruptions of ilount st. Helens in washington released large quantities of tephra or ash into the environment (Fruchter et al., 1980). Table 7 contains analytical data on the two eruptions from the mountain and 
TABLE 7. Elemental concentrations in Nount St. Helens ash from the 18 May 1980 eruption (Koranda, 1980).

\begin{tabular}{|c|c|c|c|c|}
\hline \multirow[b]{2}{*}{ Element } & \multicolumn{4}{|c|}{ Micrograms per gramı dry weight or percent by weight } \\
\hline & Yakima & Kichland ${ }^{\mathrm{a}}$ & Pullman & $\begin{array}{l}0.1 \times \text { nitric } \\
\text { acid extracted }\end{array}$ \\
\hline Potassium & 6135 & 6800 & 9240 & 64.5 \\
\hline Calcium & $2.3 \%$ & $2.5 \%$ & $1.9 \AA_{0}$ & 1238 \\
\hline Titanium & 3150 & 4100 & 2522 & $--^{C}$ \\
\hline Manganese & 620 & 550 & 456 & 21.3 \\
\hline Iron & $3.1 \%$ & $3.2 \%$ & $2.3 \%$ & 542 \\
\hline Copper & 29 & 28 & 38 & 5.4 \\
\hline Zinc & 50 & 58 & 49 & 1.7 \\
\hline Gallium & 20 & 21 & 19 & -- \\
\hline Rubidium & 19 & 23 & 36 & -- \\
\hline Strontium & 580 & 490 & 398 & 2.7 \\
\hline Yttrium & 10 & 8 & 12 & -- \\
\hline Zirconium & 80 & 99 & 151 & -- \\
\hline Lead & 7 & 5 & 9 & 0.8 \\
\hline Boron & -- & -- & -- & 0.7 \\
\hline Arsenic & -- & -- & -- & 0.7 \\
\hline Cadmium & -- & - & -- & 0.2 \\
\hline Cobalt & -- & -- & -- & 0.4 \\
\hline Nickel & - & - & -- & 0.6 \\
\hline Phospherus & -- & -- & -- & 369 \\
\hline Jranium & -- & -- & -- & 2.4 \\
\hline Vanadium & -- & - & -- & 1.3 \\
\hline Magnesium & -- & -- & -- & 459 \\
\hline Sodium & -- & -- & - & 215 \\
\hline
\end{tabular}

Analyzed by $x$-ray fluorescence analysis. b

Extracted from Yakima ash sample and analyzed by inductively coupled argon plasma emission spectroscopy.

$c_{\text {Not detected. }}$ 
one laboratory analysis of the availability of trace elements in the tephra (Korarida, 1980). The volume of ejecta released by the Mount Jt. Helens eruption of 18 May 1980 was large, estimated at $4 \mathrm{~km}^{3}$, and it the concentrations of lead, arsenic, cadmiumı, vanadium, and uranium are extrapolated to the total mass of ejecta, the inventory of released toxic elements appears large and significant. The depositional area is also very large, and excspt at adjacent locations, the ash loading is relatively light. The major immediate health concern from resuspension of the ash deposits appears to be in the free silica content of the ash rather than in the concentrations of major or trace elements (Fruchter et al., 1980).

Volcanic ejecta, ranging in size from tephra to bombs, and lava flows constitute local and at times intense sources of toxic elements. Andesitic volcanic niaterials may be highly enriched in toxic elements. Table $s$ shows the concentrations of these elemients in magmaxic sulfides (Kankama and Sahama, 1950).

Geothermal features such as fumaroles and the surrounding encrustations may have high concentrations of lead, nickel, chromium, vanadiurn, arsenic, and cadmium. The high concentrations of metals in these features undoubtediy are related to the high levels of sultides being emitted from the vents. The metals are either sublimed 1ronı the fumarolic gases or dissolved trom the surrounding rocks by the enitted acids. $A$ nigh concentration of $1.64 \%$ nickel u as found in fumarolıc enzrustatıons at the Shirane Volcano in Japan (Shima, 1457). In New Zealand, on white Island, which is an andesite volcano, lead at $1 \%$, vanadium at $0.63 \%$, and arsenic at $0.3 \%$ were found in the fumarolic deposits.

Some geothermal fluids are low in total dissolved solids, but other brines are a strong and mobile source of potentially toxic elements that may eriter surface uater systems from either natural or man-developed geothermal sites (Ireland, 1980). Considerable variation occurs in the brine composition both from one field to another and between wells in a single field. Some examples that were obtained from five California geothermal wells in the Imperial Valley (Pimental et al., 1978) are shown in Table 9. 
TABLE 8. Concentrations of trace elements in magmatic sulfides

(Rankama and Sahama, 1950).

\begin{tabular}{|c|c|c|c|}
\hline Element & Parts per million & Element & Parts per million \\
\hline Iron & 539,000 & Tellurium & 2 \\
\hline Sulfur & 404,000 & Tungsten & 2 \\
\hline Nickel & 31,400 & Platinum! & 2 \\
\hline Copper & 10,900 & Bismuth & 2 \\
\hline Zinc & 8,500 & Ruthenium & 1 \\
\hline Phosphorus & 2,500 & Antimony & 1 \\
\hline Cobalt & 2,100 & Thallium & 1 \\
\hline Manganese & 800 & Indium & 0.7 \\
\hline Selenium & 200 & Iridium & 0.4 \\
\hline Lead & 100 & Rhodium & 0.3 \\
\hline Arsenic & 60 & Gold & 0.2 \\
\hline $\operatorname{Tin}$ & 50 & Osmium & 0.1 \\
\hline Vanadium & 40 & Chromium & 0.02 \\
\hline Wolybdenum & 20 & Mercury & 0.02 \\
\hline Cadmium & 20 & Rhenium & 0.02 \\
\hline Silver & 10 & & \\
\hline Germanium & 10 & & \\
\hline Palladium & 4 & & \\
\hline Gallium & 2 & & \\
\hline
\end{tabular}


TABLE 9. Trace elemients in geothermal brines from Imperial Valley wells (Pimental et al., 1978).

\begin{tabular}{|c|c|c|c|c|c|}
\hline \multirow[b]{2}{*}{ Element } & \multicolumn{5}{|c|}{ Milligrams per liter } \\
\hline & $\begin{array}{l}\text { Salton Sea } \\
\text { well }\end{array}$ & $\begin{array}{l}\text { Westmoreland } \\
\text { well }\end{array}$ & $\begin{array}{l}\text { Brawley } \\
\text { well }\end{array}$ & $\begin{array}{l}\text { Heber } \\
\text { well }\end{array}$ & $\begin{array}{c}\text { East Mesa } \\
\text { well }\end{array}$ \\
\hline Arsenic & 11 & -- & 2.6 & 0.1 & 0.16 \\
\hline Boron & 350 & 63 & 140 & 14 & 5.4 \\
\hline Barium & 433 & -- & 363 & 3.8 & 2.2 \\
\hline Copper & 4 & 0.07 & 0.11 & 0.53 & 0.03 \\
\hline Fluorine & 9 & 2.24 & -- & 1.6 & 2 \\
\hline Iron & 2300 & 0.3 & 65 & 22 & 2.2 \\
\hline Lithium & 211 & 48 & 100 & 9.5 & 6.3 \\
\hline Magnesium & 1200 & 2.8 & 190 & 2.7 & 0.42 \\
\hline Nickel & 4 & -- & -- & -- & 0.03 \\
\hline Lead & 100 & 3.6 & 1.1 & 1.9 & 0.09 \\
\hline Selenium & -- & -- & -- & -- & 1.2 \\
\hline Strontium & 500 & -- & 340 & 53 & 38 \\
\hline Zirconium & 660 & 0.04 & 14 & 0.83 & 0.07 \\
\hline
\end{tabular}

\section{NATURALLY OCCIJRRING GEOTOXIC ELEMENTS}

The following elements will be considered as a primary focus in this discussion of naturally occurring geotoxic materials:

$\begin{array}{ll}\text { arsenic } & \text { lead } \\ \text { cadmium } & \text { selenium } \\ \text { chromium } & \text { uranium } \\ \text { nickel } & \text { vanadium }\end{array}$

There are other rather toxic elements in the Earth's crust such as indium and thallium, which are known to be toxic at low concentrations, but the eight elements above have been chosen as examples of naturally occurring elements with a known history or a strong potential for causing toxic reactions under the appropriate conditions in man or animals. 
They have been chosen for review because there is a considerable amount of information on their occurrence, availability, and toxicology.

\section{ARSENIC}

Arsenic is widely dispersed throughout nost rock types, usually at the parts per million level. It is often associated with sulfides, pyrites, cr apatite. Comimercial arsenic is obtained as a by-product from the smelting of lead, copper, silver, and gold ores. Arsenic is found in the following types of natural deposits or ore bodies.

- Skarn deposits

- Polymetallic deposits (lead, zinc, and cadmium)

- Realgar-orpiment deposits (rare)

Arsenic is used in geochemical surveys as an indicator of gold, silver, copper, lead, and cobalt. It is mobile in the surface ervironment and is found in soil, stream, grounawater, and vegetation surveys.

In the natural environment, four oxidation states are possible for arsenic: the -3 state, the metallic $(0)$ state, and the +3 and +5 valence states. The metallic state is common for the element in certain types of mineral deposits. The +3 and +5 states are common in a variety of complex minerals and in dissolved salts in natural waters. The -3 state is present in gaseous $\mathrm{AsH}_{3}$ (arsine), which may form under some natural conditions. The element most commonly asscciated with arsenic in nature is sulfur (Boyle and Jonasson, 1973).

There are about 100 arsenic-bearing minerals known to occur in nature. The principal arsenic minerals are arseno-nyrite (FeAsS), niccolite (NiAs), cobaltite (CoAsS), tennantite $\left(\mathrm{Cu}_{12} \mathrm{As}_{4} \mathrm{~S}_{13}\right)$, enargite $\left(\mathrm{Cu}_{3} \mathrm{AsS}_{4}\right)$, native arsenic (As), orpiment $\left(A s_{2} \mathrm{~S}_{3}\right)$, realgar (AsS), prousite $\left(\mathrm{AgAsS}_{3}\right)$, scorodite $\left[(\mathrm{Fe}, \mathrm{Al})\left(\mathrm{AsO} \mathrm{O}_{4}\right) \cdot 2 \mathrm{H}_{2} \mathrm{O}\right]$, bendantite $\left[\mathrm{PbFe}_{3}\left(\mathrm{AsO}_{4}\right)\left(\mathrm{SO}_{4}\right)\left(\mathrm{OH}_{6}\right)\right]$, olivinite $\left(\mathrm{CI}_{2} \mathrm{AsO}_{4} \mathrm{OH}\right)$, mimetite $\left[\mathrm{Pb}_{5}\left(\mathrm{PO}_{4}, \mathrm{AsO}_{4}\right)_{3} \mathrm{Cl}\right]$, arsenolite $\left[\mathrm{As}_{2} \mathrm{O}_{3}\right]$, and erythrite $\left[\mathrm{Co}_{3}\left(\mathrm{AsO}_{4}\right)_{2} \cdot 2 \mathrm{H}_{2} \mathrm{O}\right]$. Arsenic also occurs in nunor quantities in practically all the common sulfides and in a great variety of secondary oxidation products, particularly in sulfates and phosphates (Boyle and Junasson, i 973 ).

In aquatic systems, arsenic has an unusually complex chemistry, with oxidation-reduction, ligand exchange, precipitation, and adsorption reactions all taking place. Pollution control is poorly understood for these reasons. Wagemann (1978) examined the typical concentrations of major and minor ionic constituents in freshwater systems in an attempt to find the possible controls on total dissolved arsenic in freshwater. He selected four metals (barium, chromium, iron, and calcium) as possible 
controlling factors and studied their metal arsenates more closely in the laboratory. Ionic barium, at typical freshwater concentrations, was the most likely freshwater constituent capable of holding total dissolved arsenic to rather low concentrations.

There has been much discussion as to the natural concentrations of various species of arsenic and their interconversion. It is now generally recognized that arsenite and arsenate interconvert via the mono- and di-methylarsonic acids.

Andreae (1978) analyzed seawater from the Southern California coast and terrestrial waters trom several locations in the 1J.S. for four arsenic species: arsenite, arsenate, monomethylarsonic acid, and dimethylarsonic acid. Cienerally, arsenate was dominant. However, speciation of arsenic in natural waters is significantly influenced by biota.

These results were confirmed by the work of $W$ aslenchuk and $\mathbb{K}$ indorn (1978) in estuaries and waslenchuk (1979) in rivers. Waslenchuk and Windom (1978) found that in estuaries the only detectable species was arsenate, which remained in solution as freshwater and saltwater mixed. Complexes occurred between arsenic and low-molecular-weight, dissolved organic matter. These complexes presumably prevented adsorptive and coprecipitative interactions with the sediments and allowed the arsenic to travel to the ocean in a dissolved form. Arsenic that enters the estuary associated with particulates, however, apparently remains so and accumulates in the sediments.

Waslenchuk (1979) found that the levels of dissolved arsenic in rivers in the southeast U.S. are controlled by the availability of arsenic, by rainwater dilution, by the extent of complexation with dissolved organic matter, and perhaps by the metabolic activity of aquatic plants. Arsenic complexation by dissolved organic matter prevents adsorptive interactions between the arsenic and solid-phase organic and inorganic materials. However the particulate arsenic load may be as important as the dissolved load with respect to material transport in rivers. It appears further that those biologically mediated reactions that result in arsenic species disequilibria in the ocean and lakes have a negligible effect on arsenic speciation in rivers.

Cycling of arsenic in the aquatic environment is dominated by adsorption and desorption to sediments, when not controlled by organic matter. Arsenic may be sorbed to clays, aluminum hydroxide, iron oxides, and organic material (Ferguson and Gavis, 1972; Jackson et al.. 1978). In some areas where phosphate minerals occur, arsenate may isomorphously substitute for phosphate (Hem 1970). Inder most conditions, coprecipitation or sorption of arsenic with hydrous oxides of iron is probably the prevalent process in the removal of dissolved arsenic. In soils and underground aquifers, $\mathrm{pH}$ is also an important factor. 
Reay (1972) studied the arsenic levels in the arsenic-rich Wakato river in New zealand and related bioaccumulation of arsenic by aquatic plants to the total amount transported by the river. By estimating total biomass production and the amount of arsenic transported by the river, the author estimated that only 3 to $4 \%$ of the annual arsenic input to the river was bioaccumulated, with much of the balance being discharged to the sea and the remainder settling out with sediment at impoundments.

It is known that arsenic occurs naturally in high concentrations in various parts of the world, for example in Southwest Britain and some parts of bwitzerland as well as in New Zealand. However, the long-term effects on fauna and humans appears not to have been studied to any great extent and results are inconclusive.

The concentration of arsenic in granites, basalts, liniestone, and sandstone is approximately $1 \mathrm{ppm}$, in shale $13 \mathrm{ppm}$, and in soils $6 \mathrm{ppm}$. The arsenic concentration in seawater averages $3.7 \mathrm{ppb}$ and in freshwater $0.5 \mathrm{ppb}$. The average concentration in plants is about 1 ppm. The amount of arsenic cycled naturally is 6 to $19 \times 10^{9} \mathrm{~g} / \mathrm{y}$ and trom mining it is $47 \times 10^{9} \mathrm{~g} / \mathrm{y}$.

\section{CADMLUM}

Cadmium generally accompanies zinc and lead in its natural state. It is commercially obtained from zinc ores as a by-product. Zinc and cadmium typically occur in the following deposits.

- Sphalerite shales (copper or Kupferschiefer types)

- Concretions of sphalerite in carbonate rocks

- Skarn-type deposits

- Massive sulfide deposits

Cadmium is often associated with lead, copper, zinc, silver, gold, barium, arsenic, and manganese. In geochemical surveys it is found in soils, sediments, surface waters, and vegetation.

During the past $15 \mathrm{y}$ much research has been done to determine the hazard of cadmium exposures. Of the trace elements, only lead and mercury have received more attention by researchers.

Cadmium exists in nature in the +2 valence state. The ionic radius of the +2 ion is estimated to be $0.97 \AA$, making it one of the larger divalent ions. Cadnium is a relatively rare element that is concentrated in zinc-bearing sulfide ores (zinc to cadmium ratio is usually 100:1 to 200:1) and, consequently, is found in virtually all zinc-containing products. It occurs at an average concentration of $0.2 \mathrm{ppm}$ in the Earth's crust, and most 
freshwaters contain less than 1 ppb cadmium. Cadmum levels in seawater average 0.15 ppb. The chemistry of cadnium in surface waters and grounowaters has been reviewed by Hen (19\%2).

In natural waters, cadmium can be found in several chemical forms; for example, as simple hydrated ions, as nietal-inorganic coniplexes, or as metal-organic complexes. An understanding of the chemical speciation of cadniumi in any given situation can be based on theoretical calculations of hyarolysis, oxidation/reductıun, and organic complexatıon. Cadmium torms complexes with $\mathrm{OH}^{-}$such as $\mathrm{CdUH}^{+}, \mathrm{Cd}(\mathrm{UH})_{2}(\mathrm{aq}),. \mathrm{Ca}(\mathrm{OH})_{3}^{-}$, and $\mathrm{Cd}(\mathrm{OH})_{4}^{-2}$. However, alniost all of the soluble cadmium ions are $\mathrm{in}$ the divalent cation form up to about $\mathrm{pH}$ 9. The solubility of cadmium decreases as $\mathrm{pH}$ increases due to formation of solid $\mathrm{Cd}(\mathrm{OH})_{2}$. Patterson et al. (1977) studied the removal of dissolved cadmium by hydroxide and carbonate precipitation. A comparison of experimentally determined $\mathrm{Cd}(\mathrm{OH})_{2}$ solubility with the calculated solubility curve showed that even at the optimal $\mathrm{pH}$ for precipitation, the equilibrium solubility of cadmium is still approximately $1 \mathrm{mg} / \mathrm{liter}$. Cadmium is always found in the +2 valence state in water ano redox potential normally has little direct effect on cadmium. Inder reducing conaitions and in the presence of sulfur, however, cadmium may react to form the insoluble sulfide. Ijnder acidic conditions, $C d s$ is more soluble. In the sediments, in anaerobic digestion of waste water, and in other reducing environments where sultur is available, the solubility of cadritum may be controlled by formation of Cds (Holnes et al., 1974).

Garainer (1974), in his study of the speciation of Cadmium in natural water, found that a substantial portion of the total cadmilum in river and lake $u$ ater $u_{1} l l$ be present as the aivalent cadmium ion, the concentration of which will be inversely related to the $\mathrm{pH}$ and the concentration of organic material in the water. Humic substances usually account for most of the complexation, followed in importance by carbonates. U'shea and Mancy (1978), in their study of the effects of $\mathrm{pH}$ and hardness on cadmium speciation, found that the effects of $\mathrm{pH}$ and hardness were insignificant in trace metal-inorganic interactions. Hardness and $\mathrm{pH}$ were quite importanl, however, in trace metal-huric acio interactions. Increasing the $\mathrm{pH}$ increased the exchangeable cadnilum while an increase in hardness led to a most pronounced decrease in the humic acid interaction. Nietals responsible for hardness apparently inhibit the exchangeable interactions betueen metals and humic materials in ways that are not yet fully understood.

Guy and Chakrabarti (1976), in their study of metal-organic interactions in natural water, found that humic acids in solution and other natural complexing agents can mantain cadmium ions in a bound form at a $\mathrm{pH}$ as low as 3. The release of cadmium trom 
sediments is, therefore, apparently controlled by a combination of ion exchange and complex formation whereby the stability of the metal-organic complex aetermines the amount of metal solubilized.

Suzuki et al. (1979) in their study of a polluted Japanese river indicated that organic material is mainly responsible for the accumulation of cadmium in organically polluted river sediments. These results suggest that suspended solids of high organic content play a dominant role in the transport of cadmium in aquatic ecosystems.

Gardiner (197t) in a laboratory study found that concentration factors for mud varied between 5,000 and 50,000 depending on the type of solid, its state of subdivision, the concentration of metal ion and complexing ligands present, as well as the temperature, $\mathrm{pH}$, and hardness of the water. It appeared further that humic niaterial was the major component of sediment responsible for adsorption.

In contrast, Perhac (1974b) found that most of the cadmium in the bottom sediments of an unpolluted Tennessee stream was associated with carbonates and (to a lesser extent) iron oxides and therefore hypothesized that caomium occurs in cation lattice sites within the carbonate minerals.

Kamamoorthy and Rust (1978), in their study of Ottawa River sediments, found that although the sediment was composed mainly of well-sorted sand, it was an efficient sink for heavy metals including cadmium. They discovered that this was because $\rightarrow$ the significant amount of organic material added to the sediments by the commercial use of the river for logging. Both sorption and desorption were controlled by the nature of total heavy rietal loading, the sediment type, and the surface water characteristics.

The adsorption of cadmium on soils and silicon and aluminum oxides was studied by Huang et al. (1977). The results of this laboratory study indicate that adsorption is strongly $\mathrm{pH}$ dependent, increasing as conditions become more alkaline. When the $\mathrm{pH}$ is below 6 to 7, cadmium is desorbed from these materials. Cadmium has considerably less affinity for the absorbents tested than do copper, zinc, and lead and thus might be expected to be more mobile in the environment than these materials.

Another relevant observation of Huang et al. (1977) was that addition of anions to the aissolved cadmium caused an increase in adsorption. Humic acid was most effective in this regard.

Cacmilur is strongly accumulated by most organisms in pclluted waters. Cadmium is accurriblated in the tissues of aquatic marine organisms. Fish accumulate cadmium most readily in the liver, kidneys, and intestines and to a lesser extent by the gills and the remainger of the body. 
The influence of hardness on uptake of cadmium by a mcrocosm containing an alga, a rooted plant, snails, catfish, and guppies was studied by Kinkade and Erdmian (1975). They found that initial uptake of cadmium was faster in hard than in suft water, but that the total concentration of cadmium was greater in the organisms that were placed in soft water. The relative bioaccumulation factors descended in the following order: root $a d$ plant $\rightarrow$ alga $\rightarrow$ guppies $\rightarrow$ snails $\rightarrow$ catfish.

Cadmium is readily accumulated through both tood and water by freshwater organismis, and either source of uptake can result in the development of toxic symptoms by fishes.

\section{CHROMIIM}

Chromium is widely dispersed in all rock types, having the highest concentration ir: mafic or ultramafic igneous rocks. The ore mineral is chromite, and most commercialiy' useful deposits of the ore occur in ultramafic rocks as ore bodies, lenses, or other inclusions. Chromium is evident in all ecological phases except water. Nickicl and cobalt are used as indicators of chromium in geochemical surveys in which stream sediments and waters are sampled.

Chromium is a transition element and occurs in nature principally as the trivalent ion $\mathrm{Cr}^{+3}$, although valence states ranging from -2 to +6 have been reported. The two main forms of chromium are $\mathrm{Cr}^{+3}$ and $\mathrm{Cr}^{+6}$. Chromium ore is always tound in conjunction with other metals as an oxide (such as ferrochrome). The two largest deposits are in South Africa and the Soviet Union. Zimbabwe, which was long considered a large and important source, has declined recently in importance because of the deposits being worked out. Chromium is found in concentrations of about 10 to $100 \mathrm{Ppm}$ in the crust and about 0.001 to $0.8 \mathrm{ppm}$ in river waters. The principal chromium-bearing minerals belong to the chromite spinel group with the general formuia L(Mg, $\mathrm{Fe}) \mathrm{O}(\mathrm{Cr}, \mathrm{Al}, \mathrm{Fe})_{2} \mathrm{O}_{3} \mathrm{~J}$. Depending on the degrees of substitution in the $\mathrm{Cr}, \mathrm{Al}$, Fe series, the chromites contain from 13 to $65 \% \mathrm{Cr}_{2} \mathrm{O}_{3}$.

Chromite is generally resistant to chemical weathering. Because of its high specific gravity, it can be mechanically concentrated in iaterites or heavy mineral placers. The chromium-bearing silicates release chromium, which is then incorporated into shales and schists. Little chromium becomes solubilized, and thus geological precipitates and evaporites normally have a low chromium content.

Trivalent chromium is the most stable form under redox conditions normallv found in natural waters and sediments, and when in solution at $\mathrm{pH}$ greater than $5, \mathrm{Cr}^{-3}$ quickly precipitates due to formation of the insoluble hydroxide or oxide. 


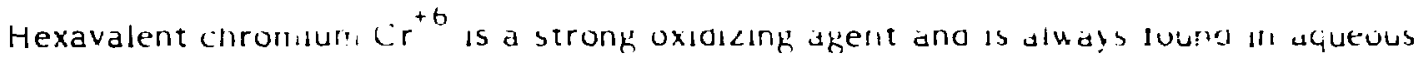
solution as a component of a complex anion. The anum: iom varies actorang to ph

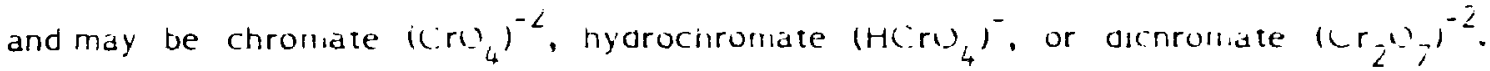
Dichromate concentration is not significant unless pH values are well delou tnose observed in most natural waters. Thus, hexavalent chromium present in nost naturai waters $\left(\mathrm{pH}_{2} 6.5\right)$ will be in the form of the chromate ton $\left(\mathrm{Crc}_{4}\right)^{-?}$. Wh of the antunk forms are quite soluble and thus are quite modile in the aquatic environment lioulli $\underline{E}$ al., 1975).

Schroeder and Lee (1975) in a laboratory study on the transformation of chromburil in natural waters, found that $\mathrm{Cr}^{3}$ and $\mathrm{Lr}^{+6}$ are readii interconvertiole under naturat conditions. Their results indicated that $\left(i^{\cdot 6}\right.$ can be reduced by $1 e^{\cdot ?}$, dissolved suilides, and certain organic compounas uth sulthyaryl groups. wimle $i^{+3}$ can be oxadzec at a large excess of $\mathrm{hnO}_{2}$ and at a slower rate $\mathrm{Dy}_{2} U_{2}$ unger nitural hater conditioris. Moreover, it aquatic conditions favor $\mathrm{Cr}^{+6}$, then chromiain will accuriulate ds soluole forms in waters: it nowever $\mathrm{Cr}^{+3}$ is favored, then the accumulation uill uccur in thit sediments. The environmental accumblation of $\mathrm{Cr}^{+3}$ in the sedillents can be explanea u: the hydrolysis of $\mathrm{Cr}^{+3}$ complexes to unsoluble hydroxide forms, espectally (rothi ${ }_{3}$.

Hexavalent chronium is not absorbed to any signilicant degree oy clays, terru hydroxide, or ferric ano manganese oxides (Kharkar et al., Iyb\$). The (ir inal. however, have some aftınity for organic materals in natural uaters. It appears that while $\mathrm{Cr}^{+3}$ is only weakly absorbed on inorganic solıds, it is udsorbed more strongly inall $\mathrm{Cr}^{+6}$, but the sorption of $\mathrm{Cr}^{+3}$ may be ancillary to precipitation of (r(OH) $3^{\text {. }}$

Chromium is accumulated in aquatic and marine olota to levels much higher than in ambient water. Levels in biota, houever, are usually lower than levels in sedirients.

Namminga and Uilhm (1977) studied heavy metal parmtioning betueen water. sediments, and chironomid larvae (a benthic invertebrate). They tound an average chromium concentration of $1.1 \mathrm{ppb}$ in water, 7.64 ppm in secinients, and 2.46 ppril in chironomids. Bioconcentration factors for chironomids to water are thus about 3.000 ano for chironomids to sediments, about 0.39. Rehwoldt et al. (1975) tound smmilar relationships among water, sediments, and biota in the Danube River.

Baptist and Lewis (1969) studied the transter of radiolabeleo $\mathrm{Cr}^{*}$ in an estuarine food chain consisting of phytoplankton, brine shrimp, postlarval fish, and mumruchoj. In general, the foud chain was a mure etficient pathuay lor uptake of chromun than direct uptake frorn seauater. 


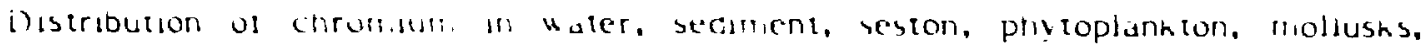

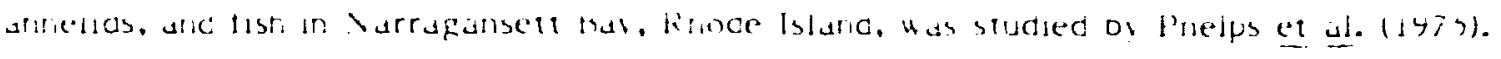

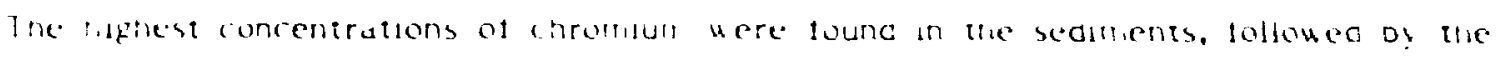

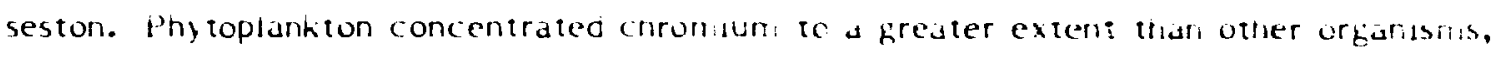
with the low est levels velng lound in butroni-feeanf ish.

MiKLL

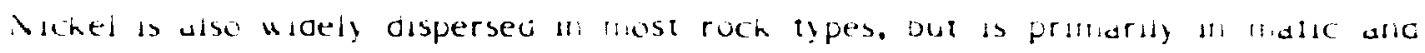

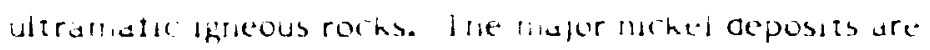

- Mlassive sultive lenses.

- verns ara lenses ol sultices sno arsenices, ano

- Laterinc michel-codalt deposits (garmerite).

Whet is a juvi sell-mokator ul deposits in feochentical surveys, uith elevated local concentrations deing seen in suls, sedments, water, arid vegetation. Precipitates at spring wouths liat also indicite the presence of fuchel me region.

vickel is a naturally occurring element that is found in the farth's crust at an average concentration of 75 ppre. Nickel is nomally avalent in its compouncs. unict: ire predorinanty iunic in character. It is sideropnlic and will alloy itselt with metalic iron whenever tus phase is present. Nickel is unly shighty misciole in iron, and ue two phases separate at low temperdures. The Larth's core is thought to de a mackei-iron

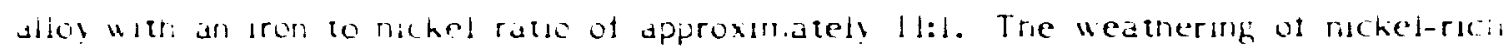
vearock fives rise to ironi-, nickel-, ang silica-rich solutions. Ionic nickel is very stable m aqueous solutions a.to is capaule of migration over long astances. The nigh attanity ul nichel for sulfur accounts for its occurrence in magmatic or nietamorphic segregates of sultide Dodıes. These sultıde segregates compose the large nickel ore dody at sudbury. Intario, which provices the worlo's largest inung proauction ol nickei.

Nickel is aivalent in aquatic systems. I nder reaucing conotions and in the presence of sulfur. the insoluble sulfiae is tormed. Ender aerodic conditions and pti beluw $y$, the compounas that nickel forms with hyaroxide, carbonate, sultate, and naturally vccurring organic ligands are sulifiently soluble to mantaln aqueous $\mathrm{N}^{+2}$ concentrations above $10^{-6} \mathrm{~N}(66 \mathrm{ug} / \mathrm{liter})$. Above $\mathrm{pH} y$, precipitation of the hyoroxide or carbonate inhibits nickel inoolat!.

Hyarolysis of aqueous nickel to the hydroxide $\mathrm{V}_{1}\left(\mathrm{l}(\mathrm{H})_{2}\right.$ is signaficant only under basic conations. Patterson et al. (1977) comparea the precipitation dehavior ot nickel rarbonate and nickel nydroxide in the context of treatment of nickel-bearing waste eflluents. Although precipltailon as the hydroxide uas tound to be the more etlicient 
treatment, the lowest nickel concentration attained at $\mathrm{pH}$ values below $y$ was $15 \mathrm{mg} / \mathrm{llter}$. This level is quite high with regard to its toxicity and indicates that precipitation is not an elfective control of nickel under most conditions.

In natural waters, humic acids alter the solubility and precipitation behavior of nickel. Rashid ano Leonard (1973) exposed nickel carbonate to humic acid and found that complexation with humic acid solubilized much of the nickel. Sorption of nickel hydrous iron and manganese oxides and organic material probably exerts the major control on the mobility of nickel in the aquatic environment. Nickel, however, is a highly mobile metal and is sorbed only to a small extent, except in the presence of organic compounds. Lee (1975) presented cogent evidence for the importance of hydrous iron ana manganese oxides in controlling nickel concentrations in aquatic environments.

However, Perhac (1972, 1974a) found that almost all of the nickel transported by two Tennessee streams was in the dissolved form. The reason for this discrepancy is probably the fact that about $90 \%$ of the solids in the streams studied by Perhac were dissolved solids, so that there were very few suspended particles available for coprecipitation/ sorption reactions.

The partitioning of nickel to dissolved and particulate tractions is unooubtedly related to the abundance of suspended material, competition with organic material, and concentrations of iron and manganese.

suspenced organic matter may be a good adsorbent tor nickel. Rashid (1974) useo collordal humic substances to adsorb nickel and tound that of the nickel thus bound, only $26 \%$ could be extracted by anmonium acetate.

Nickel is bioaccumulated by sorre aquatic organisms, but most concentration factors are less than $10^{3}$. Tong (1974) showed that nickel does not bioaccumulate in lake trout Salvelinus namaycush. In a study of the accumulation of iron, zinc, lead, copper, and nickel by algae collected near a zinc smelting plant, it was found that nickel exhibited the lowest concentration factor for all metals tested (Trollope and Evans, 1976). In general. nickel is not accumulated in significant amounts by aquatic organisms.

\section{LEAD}

Leac occurs in a variety of deposits, usually those that also contain zinc, cadmium, aria copper. The best indicators of lead deposits are zinc, cadmium, silver, copper. Dariuri, arsenic, and antimony. The natural compounds of lead are rather insoluble and geochemical surveys of surface water are not effective. Spring precipitates, however, may incicaie the presence of regional lead deposits. 
The average concentration of lead in the Larth's crust is approximately 13 ppri, which is equivaint to one-half ounce of lead per ton of rock. Lead is a major constituent of more than 200 identified munerals. Niost of these munerals are rare, and only three are found in sutficient abundance to form ores: galena (PbS), the simple sullide; angelesite $\left.(\mathrm{PbSO})_{4}\right)$, the sulfate; and cerrusite $\left(\mathrm{PbCO}_{3}\right)$. the carbonate. by tar the most abundant is galena, which is the priniary constituent of the sulfıde ore deposits fromi which most lead is presently mined. Lead ore is commionly present together with ores of copper, zinc, silver, arsenic, and antimony in complex vein deposits, but lead ure also may uccur in a variety of ıgneous, metamorphic, and sedmentary rocks.

The tendency tor lead to torm complexes with naturally occurring organic materlals (e.g.. humic and fulvic acids) increases its adsorptive aftinity tor clays and otner muneral surfaces. However, natural compounds of lead are not usually modile in normal grounawater or surface water because the lead leached trum ores becomes adsorbed by lerric hydroxide or tends to combine with carbonate or sulfate ions to torm insoluble compounds (Hen, 1976a).

An outstanding characteristic of lead is its tendency to form conplexes of lou solubility with the major anions of natural environmental systenis. The hydroxide, carbonate, sulfide, and (more rarely) the sulfate of lead may act as solubility controls. Throughout most of the natural environment, the divalent form $\mathrm{Pt}^{+2}$ is the stable ionic species of lead. The more oxidized solid $\mathrm{PbO}_{2}$, in which lead has a +4 charge, is stable only under highly oxidizing conditions and probably has very little significance in the aquatic environment. It suifur activity is very low, metallic lead can be a stable phase in alkalıne or near neutral reoucing cunditions.

Hem (1976b) calculated the fields of stability for solid species of lead based on the avallable thermodynamic data. Although his figures are useful in depictıng equilibrium behavior, they are limited in that they do not take into account environmental interactions with organic compounds and other trace elements and, therefore, may be misleading with respect to late and transport in normal surface waters. Hem (1976a) also modelled the equilibrium distribution between lead in solution and lead adsorbed on cation exchange sites in sediments. In general, this model suggests that in most natural environments, sorption processes would more effectively scavenge dissolved lead than u ould precipitation.

Lead exists mainly as the arvalent cation in most unpolluted waters ano becomes sorbed to partıculate phases and organic material in polluted waters.

Sorption processes appear to exert a dominant effect on the distribution of lead in the environment. Several investigators have reported that in aquatic ano estuarine systenus, lead is removed to the bed sediments in close proximity to its source, apparently 
due to sorption onto the sedimients (Helz et al., 1975; Valiela et al., 1974). Ditierent sorption mechanisms have been invoked by different investigators and the relative importance of these mechanisnis varies widely with such paramieters as geological setting, $\mathrm{pH}$, Eh, availability of liganos, dissolveo and particulate iron concentration, salinity, composition of suspended and bed sediments, and initial lead concentration.

The adsorption of lead to soils and oxides was studied by Huang et al. (1977). The data indicate that adsorption is highly $\mathrm{pH}$-dependent, but above a $\mathrm{pH}$ of 7 , essentiaily all of the lead is in the solid phase. It should be noted that at low $\mathrm{pH}$, lead is negatively sorbed (repelled from the adsorbent surface). The addition of organic complexing agents increases the affinity for adsorption. Therefore, the tendency for lead to be adsorbea probably reflects the fact that lead is strongly complexed by organic miaterials in the aquatic environment (Ramamoorthy and Kushner, 1975).

Sorption processes appear to be effective in reducing dissolved lead levels and result in enri-hment of bed sediments. It appears that under most conditions, adsorption to clay and other mineral surfaces, coprecipitation/sorption by hydrous iron oxides, ano incorporation into cationic lattice sites in crystalline sediments are the important sorption processes.

Several authors, notably Jenne (1968), Lee (1975), and Hohl and Stumm (1976) have hypothesized that the sorption of heavy metals by hydrous iron and naanganese oxides is a major control on the mobility of these pollutants in the aquatic environment.

Bioconcentration of lead has been demonstrated in a variety uf oryanisms; however, some microcosm studies indicate that lead is not biomagnitied. Lu et al. (1975) studied the fate of lead in three ecosystems differing only in their soil substrate. The ecosysteris contained algae, snails, mosquito larvae, mosquito fish, and microorganisms. Lead was concentrated most by the mosquito larvae and least by the fish. Body burdens and aqueous lead concentration appeared to be strongly correlated to the percentage of organic matter and cation exchange capacity of the soils, indicating that the availability of lead in the systems was controlled by adsorption to the soils. Since pH was the same for all three soils, precipitation/dissolution of inorganically bound lead was probabiy not responsible for the differences in lead availability and uptake.

Merlini and Pozzi (1977a) measured lead uptake in pumpkinseed sunfish (Lepomis gibbosus) exposed to ${ }^{203} \mathrm{~Pb}$ at $\mathrm{pH} 6$ and 7.5. Fish in water at a $\mathrm{pH}$ of 6 accumulated three times as much lead as fish kept at pH 7.5. Gill, liver, and fin accumulated the most lead and muscle the least. The authors attributed the increased lead uptake at low $\mathrm{pH}$ to the increasing concentration of divalent lead with decreasing $\mathrm{pH}$. In another experiment, Merlini and Pozzi (1977b) found a direct correlation between lead accumulation by 
pumpkinseed sunfish and the concentration of ionic lead in water at various concentrations of total lead. Results suggest that the conditions existung in the m-jority of natural waters render most lead unavailable for accumuldtion by aquatic anima!s.

Patrick and Loutit (1976) studied uptake of lead by benthic bacteria and subsequent transfer to tubificid worms. The concentration factor for bacteria was approximately 360. Concentration of lead by tubificids was 0.77 times the amount ted then in the bacteria, indicating that the tubificios can clear lead more easily than the bacteria. The fact that the bacteria could concentrate lead indicates that lead in the sedirrients can be remobilized by bioaccumulation.

based on available information, it appears that tish accumulate very hitle lado in edible tissues; however, oysters and inussels are capable of accumulating high levels if lead. Derceasing $\mathrm{pH}$ increased the avalability of divalent lead. Lead can be methylateo by microorganisrus present in lake seaiments. The volatile cuiripound resulting trom biomethylation, that is, tetramethyl lead, probably leaves the sediments and is elther oxioized in the water slumn or enters the atmosphere. Biomethylation represents a process that enables lead in the bed sediments to be reintroduced to the aqueous or atmospheric environment.

\section{SELENIUM}

Selenium is widely dispersed in various rock types at low concentrations. It is particularly concentrated in sulfides. Most of the commercially extracted selenium is derived from polymetallic ores such as copper, mercury, and silver. selenium is a good indicator element for sandstone deposits of uranium, gold-silver selenide ores, and the polymetallic ores containing copper, silver, and mercury. Many western range plants concentrate selenium from the soil and produce concentrations in the thousands of parts per million. For example plants such as locoweed, vetch, or Astragalus can concentrate seleniurn to the point where it causes sickness and mortality in range cattle. On the other hand, deficiency of the same element in northeastern glaciated soils causes pour growth and reproduction, hoof problemis, and the so-callea white muscle disease in ungulates.

Principal positive oxidation states for selenium are +4 and +6 and in a tew unstable compounds, +2 . In selenides, selenium assumes the oxidation state of -2 . Selenium 1ormis compounas analogous with sulphur compounds including bromides, chlorides, nitrides, oxides, oxy-salts, and sulfides. In the solid state, selenium exists as the se, molecular form, while in the vapor phase, decomposition to the $\mathrm{se}_{2}$ form takes place. 
Selenium has an average crustal abundance of $0.05 \mathrm{ppm}, 0.6 \mathrm{ppm}$ in shales, $0.05 \mathrm{ppm}$ in sandstones, and $0.08 \mathrm{ppm}$ in carbonates. Many sulfide ores are selenium enriched. belenium forms selenides and sulfo-selenides of silver, copper, lead, and mercury. Minerals that may bear selenium are galena (Pbs), sphalerite (LnS), chalcopyrite (CuFes 2 ), pyrite $\left(\mathrm{FeS}_{2}\right)$, and arsenopyrite (AsFeS). Minerals in which selenium forms an essential component have only been identified in a few deposits. High concentrations (up to $\$ 48 \mathrm{ppm}$ ) of selenium are found in limonitic concentrations in the basal portion of the Niobrara Formation of Central and Southeastern yoming.

The selenium content of rocks varies with difterent geological formations. Processes contributing to the enrichment of selenium in geological materials include mechanical enrichment, precipitation, adsorption, substitution, and presence of organic materials (Krauskopf, 1955). Highly seleniferous volcanic tuffs have been reported in wyoming that can contain up to 187 ppm selenium (Rosenfeld and Beath, 1964). Other selenium-bearing rocks include carbonaceous shales, lignites, phosphates, ferruginous sandstones, and limestones. High selenium concentrations also have been associated with uranium-vanadium ores.

Selenium normally does not occur in water in sufficient amounts to produce selenosis in man or animals (Rosenfeld and Beath, 1964). Selenium in water is primarily caused by leaching from seleniferous plants, but these concentrations are usually less than 0.1 ppm. Large amounts of selenium are carried in solution to the sea, but they are largely removed from the aqueous solution by adsorption on precipitated hydroxides of iron and manganese, organic matter, and sulfides. Enrichment of selenium by sedinientary iron ores explains the higher than crustal abundance in these ores. Marine waters typically contain 3 to $6 \mathrm{Ppb}$ selenium (Rosenfeld and Beath, 1964).

Selenium in soil may be derived from (1) formations or rock outcrops, (2) rocks lying beneath the soil mantle, (3) weathering of parent rocks and transport by grounawater or surface water, (4) indicator plants, and (5) man-caused enrichment from mining or ore processing. Various selenium compounds in soils differ in their solubility in water. Selenides, selenates, organic selenium compounds, and some elemental selenium may be present in soils; some are readily adsorbed by the vegetation. The compounds most available for plant absorption are organic selenium compounds and selenates. Selenium content in soils averages $0.2 \mathrm{ppm}$, but in highly seleniferous areas, surface soils may contain from 1.5 to $20 \mathrm{ppm}$.

Certain plants accumulate high concentrations of selenium when they grow in seleniferous soil or geological formations. Primary accurnulator plants require selenium for their growth and development. Secondary selenium absorbers are different species 
that accumulate moderately large amounts and thus are an aid in locating seleniterous deposits. Selenium-accumulating plants often play an important role in converting absorbed selenium to soluble compounds that are readily available for absorption by all types of vegetation.

\section{IJRANIUM}

Uranium is widely dispersed in all three major rock types (igneous, netamorphic, und sedimentary), but mainly occurs in the following specific types of deposits.

- Granitic rocks

- Calcite-fluorite-apatite deposits

- Veins, lodes, and igneous dikes (pitchblende)

- Sandstone deposits

- Pyrite-quartz conglonerates

- Carbonatites

- Black shales

- Phosphorites

- Coal and lignite

- Placer deposits

Indicators of uranium are phosphorus, fluorine, cobalt, nickel, and arsenic in soils $\Rightarrow \mathrm{d}$ sediments. Uranium is, however, a good indicator of its own deposits in all typer of geochemical surveys, including radioactivity measurements. Selenium is used sometımes as a uraniumi indicator, and the presence of darkened of colored carbonate and quartz deposits created by radiation effects is also used.

The average concentration of uranium in the Earth's crust is 1.8 pprı. Granites and shales contain an average of $3.7 \mathrm{ppm}$, while carbonates have $2.2 \mathrm{ppm}$ and sandstones $0.45 \mathrm{ppm}$. An estimate for seawater is $0.001 \mathrm{ppm}$. The total uraniun content of the Earth's crust to a depth of $25 \mathrm{~km}$ is calculated to be $10^{17} \mathrm{~kg}$ and the oceans contain $10^{13} \mathrm{~kg}$.

A few important uranium minerals are uraninite $\left(U_{2} O_{2}\right)$, euxenite-polycrase $l(Y$, Ca, $\left.\mathrm{Ce}, U, \mathrm{Th})(\mathrm{Na}, \mathrm{Nb}, \mathrm{Ti})_{2} \mathrm{O}_{6}\right]$, brannerite $\left[\left(\mathrm{Y}, \mathrm{Ca}, \mathrm{Fe}, U_{,} \mathrm{Th}\right)_{3}(\mathrm{~T} 1 \mathrm{Si})_{5} U_{16}\right]$, cotfinite (USiO ${ }_{4}$ ), autunite $\left[\mathrm{Ca}\left(\mathrm{VO}_{2}\right)_{2}\left(\mathrm{PO}_{4}\right)_{2} \cdot \mathrm{H}_{2} \mathrm{O}\right.$, and uranophane $\left[\mathrm{Ca}\left(\mathrm{UJO}_{2}\right)_{2} \mathrm{Si}_{2} \mathrm{O}_{7} \cdot \mathrm{H}_{2} \mathrm{O}\right]$. Liraninite may occur in pegmatites, but at such low concentration that they are of little economic significance. Pitchblende, found in hydrothermal veins, is the most important ore ana is usually associated with sulfides. Near-surface uranium ores are usually oxidized. 
Important uraniun producers are the sandstone-type Colorado Plateau deposits ; the conglomerates of blino Kiver, Untario; and the reef deposits of the Hitwatersand, South Africa. Vein deposıts at Great Bear Lake and Lake Athabasca, Canada are also imiportant sources. Low-grade uranium ( 0.005 to $0.02 \%$ ) is present in phosphate deposits, bituminous shale, and lignites.

Lranium exists in tour oxidation states in solution, but only $\mathrm{J}^{+4}$ and $\mathrm{J}^{+6}$ are stable. Hexavalent uranium lorms the uranyl ion $\left(\mathrm{jO}_{2}\right)^{+2}$, which in turn forms cormplexes with many anions (tluorides, chlorices, bromides, etc.).

The most important oxides of uranium are $\mathrm{JO}_{2}, \mathrm{~J}_{4} \mathrm{O}_{9}, \mathrm{~J}_{3} \mathrm{O}_{8}$, and $\mathrm{JO}_{3}$. At elevated temperatures, uranium and oxygen torm extensive solid solutions.

Thermodynanic data show that $\mathrm{Jj}^{+4}$ is less stable than $\mathrm{Ij}^{+6}$. The $\mathrm{Ij}^{+4}$ species tends to precipitate as insoluble uraninite and coffinite. Uranium in natural waters is isually complexeo, and these complexes greatly increase the solubility of uranium minerals in surface water and groundwater (Langmuir, 1978).

Grantic rocks have a relatively high uranium content and are the presumed source rocks for many sedimentary uranium deposits (Langmuir, 1978).

VANADDIIH

Vanadium is widely dispersed in most rock types at low concentrations. basic rocks usually contain the highest concentrations and vanadium is found in a large number of minerals, including sulfides. Vanadium occurs in the following types of deposits.

- Tıtanıferous magnetite aeposits

- Lraniferous sandstones

- Asphalt and other hydrocarbons

- Polymetallic deposits (copper, lead, and zinc)

- Phosphorites and vanadiferous shales

- Sedimentary iron ores

- Petroleum and coal deposits

- Placer deposits containing magnetite

$V$ anadium is a good indicator of its own presence in the surface environment and is evident in soils and stream sedinıents. Stream and spring precipitates are enriched in vanadium when it is present in the region. 
Vanadium does not naturally occur as a tree mietal but as relatively soluble salts, comimionly in the trivalent state. Important vanadium minerals are patronite $\left(V_{2}{ }_{5}+n\right)$, carnotite $\left(\mathrm{K}_{2} \mathrm{O} \cdot 2 \mathrm{JO}_{3} \cdot \mathrm{V}_{2} \mathrm{O}_{5} \cdot 3 \mathrm{H}_{2} \mathrm{O}\right)$, vanainite $\left[\mathrm{Pb}_{5}\left(\mathrm{VO}_{4}\right)_{3} \mathrm{Cl}\right]$, and desclolzlte $\left[4(\mathrm{~Pb}, \overline{i n}) \mathrm{O} \cdot \mathrm{V}_{2} \mathrm{O}_{5} \cdot \mathrm{H}_{2} \mathrm{U}\right]$. Ultramafic rocks (peridotites) and matic shales contån an average of 200 Ppm vanadium; granites contain an average of 16 ppm. Soils in the L.S. may contain $200 \mathrm{ppm}$ with clays usually the highest $(300 \mathrm{ppm})$. Average crustal abundance is 135 ppm.

The most important natural sources of vanadium are marine aerosols, continental dust, and volcanic activity (Duce et al.. 1975). An estimate of the total oceanic inventory is $7.5 \times 10^{12} \mathrm{~kg}$, even though only about $0.001 \%$ of the vanadium entering the oceans is retained in the soluble form.

Most of the environmental vanadium originates from man's industrial activity, primarily from the combustion of oil to produce electricity. In the coking of coal, there is little emission of vanadium to the air because most of it remains in the coke.

Vanadium exists in four valencies: pentavalent $\left(V_{2} \mathrm{O}_{5}\right)$, tetravalent $\left(V \mathrm{O}_{2}\right)$, trivalent $\left(\mathrm{V}_{2} \mathrm{O}_{3}\right)$, and divalent ( $\left.\mathrm{VO}\right)$. The pentavalent oxide dissolves in alkalies to form vanadates

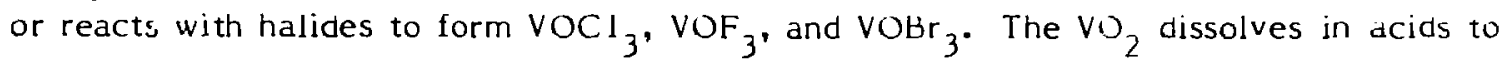
form salts (e.g., VOSO 4 ); trivalent and divalent oxides are insoluble in water and alkalies, whereas divalent vanadium oxide dissolves in acid to form salts.

Vanadium enters the body mainly via the respiratory route and has been found in many humian lung samples. The next highest concentration in human tissue is the lower small and large intestines.

Vanadium uptake by plants and animals is variable and depends somewhat on its availability in soils. Seafood is generally higher in vanadium than other foods (Hopkins and Mohr, 1971). Only about $1 \%$ of the ingested amount is absorbed from the human intestine and that quantity absorbed is rapidly excreted (60\% in $24 \mathrm{~h}$ ). Because of its low absorption and rapid excretion, vanadium is less toxic than many other trace metals.

No data in the pertinent literature suggests that vanadium is carcinogenic or mutagenic to man. Occupational exposures to the element may result in irritation of the mucous membranes of the respiratory tract, resulting in the possiblity of severe chronic bronchitis. 


\section{DISCUSSION OF ELENENTAL TOXICITY}

The relationship of essential, nonessential, and toxic trace elements in the soil and parent materials of a region to the health and prevalent aiseases in man and animals of that region has received increased attention during the past two or three decades (Kovalsky, 1974; Lag and Bolviken, 1974; Fortescue, 1974). Numeious reports have directly addressed the subject of naturally occurring toxic elements ano their relationship to animals and man (Cannon, 1974; Lough et al., 1979). Cuntinued research on the interrelationships of endemically high or low concentrations of trace elemeris incluaing those of anthropic orıgin) and disease states (geomedicine) niay reveal how jmportant the local occurrence of geotoxic materials are to the general welfare of man ( $\mathrm{w}$ arren, 1974; Gould and Warren, 1980). The weakening philosophy that all or most disease states nave a microbial origin may eventually be reevaluated in view of the data being obtaineo in modern research in the embryonic science of geomedicine.

Sonie of the elements discussed here have the ability to cause toxic effects in animal food chains and in human nutrition, especially where the elements are derived from water or tood. Of the eight elements, naturally occurring arsenic and selenium have the rrost notable physiological effects in animals and man. Examples of water contamination with arsenic have occurred in Chile (Borgono and Greiber, 1971) . nd Alaska (Hawkins et al., 1980) where the local population becalle intoxicated from waier supplies that contained elevated levels of arsenic derived fron a local geochemical source. Jelenıum toxicity has occurred throughout the il estern lj.S. in range cattle that typically acquire the elemient from several accumulator species of range vegetation (ciough et al., 147y).

wany of the eight elements discussed here reach man in significant quantities from various anthropic activities that can and usually do overwhelm any natural pathways. Lead and cadmium are examples of elements with strong anthropic sources, and the inventory of lead and cadmium released by automobile exhaust and industrial outfall, respectively, exceed releases from any other known sources. Kecent research by burau et al. (1980) has shown that endemic geochemical sources of cadmium can occur and may: affec: regional agricultural products. Natural arsenic, seleniun, and uraniun deposits (often associated with each other) may produce locally elevated concentrations of those elements in soils, sediments, and surface water. This is, in tact, the basis of geocnenical prospecting techniques widely used in obtaining commercial deposits of these and other elements. 
Lndoubtealy it can be denionstrated that under typical cultural conalions, all or miost of the elements considered here reach man primarily as the result of technological, agricultural, and other anthropic activities rather than trom local geocnenucal sources. Uf the eight elements, five are known carcinogens (chropigm, nickel, selenium, cadmum, and lead). The physiologically essentiat elements in the series are arsenic, chromilum, nickel, selenium, and perhaps vanadium (Nertz, 1981).

Stimulatory effects have been observed when vanadium has been added to the diet of animals. The requirements for essentiality of any elenient are as follows (D)ulki ani Risby, 1976).

- The presence of the element in the newborn or fetus.

- Homeostatic regulation of the element.

- Existence of a metabolic pool of the elenient, specifically influenced by hormonal or physiological processes.

- Presence of a metallo-enzyme in which the element occurs.

- Uccurrence of a deficiency syndrome that can be eliminated by the ingestion ol trace amounts of the element.

It is possible that essentiality can be demonstrate. 1 in one class or taxon of organisms and not in others. For example, vanadium is essential to ascidians and marine invertebrates, but may not be required by other animals, including mammals.

In relating the biological effects of one material to another, it should be inderstoud that rigorous and precise comparisons are impossible. This is particularly the case in comparing toxic inaterials that are essential metabolites in low concentration to those apparently having no threshold levels for exhibiting harmful elfects. Also, it must be realized that different toxins may exhibit different physiological effects, and it is somewhat tenuous to compare the severity of such effects to each other. For example, it is difficult to relate a kidney poison to a carcinogen, except perhaps at the extreme effect of death itself.

The approach adopted in this study is that harm or detriment, in itself, can be a useful scale and that at relatively low doses (which for geotoxic exposures are of overriding importance), relative comparisons, although not rigorous, can provide useful insights and perspectives on detriment.

In the case where radiation effects are related to chemical etfects, many believe that any comparison is invalid because miany stable elements have been shown to be essential metabolites at low dosage, while radiation is reputed to nave no threshold for harmful effect. It should be pointed out however, that the latter observation is, as yet, theoretical. In fact, radiation also has been reported to exhibit stimulatory effects at 
low doses (hormesis) (Luckey, 1980). Therefore, considering our present state of knowledge in this regard, it may be concluded that relating low-dose detriment of radiation to chemical toxins can be considered a valid approach.

Toxicity of the eight elements considered here can be described in a concise way by the lethal dose from oral ingestion (oral $\mathrm{LD}_{50}$ ) determined in small mammals in laboratory experiments. Table 10 shows the oral $\mathrm{LD}_{50}$ concentrations for the eight elements. Two of the elements have large oral LD 50 values (nickel and uranium), ano these values depend largely on the compound or elemental form administered. Generally arsenic, seleniurn, and cadnium have the lowest oral $\mathrm{LD}_{50}$ values and the highest toxicity. As was noted, arsenic and selenium have caused health problems in man and animals from low chronic exposures to elevated natural levels.

Anthropic sources of these elements nay deliver inventories to the environment tar greater than any other known sources of geochemical deposits, although many geochemical sources are extremely large. Netallic emissions from all industrial ano technological sources in 1970 for the eight elements are shown in Table 11 (Dulka and Risby, 1976). The largest source is automotive lead, which far outweighs all other metallic releases to the environment. The emission of lead by autos, although decreasing for various economic and technological reasons, is affecting the health of the urban population despite predictions by petroleum industry scientists rade when alkyl lead compounds were tirst introouced (Warren, 1974; Zook, 1978). In 1972 the total lead use was $1.44 \times 10^{6}$ ton, of which $19.3 \%$ was on-highway fuel anti-knock lead and batteries (Osweiler and Vancielder, 1978). The major route of exposure is apparently inhalation of lead particulates that, coupled with the lung absorption of approximately $50 \%$, produces physiologically significant lead corcentrations in the blood of city dwellers, especially children (Poole and Smythe, 1980; Warren, 1974). Additional lead intake occurs from the use of processed foods and tobacco (Settle and Patterson, 1980).

The eight elements discussed here can be arranged in two groups.

- Group 1 -- Toxic essential elements: arsenic, selenium, chromium, and nickel

- Group II -- Toxic nonessential elements: cadinium, lead, uranium, and vanadiun

Two of the most toxic elements, arsenic and selenium, are found in the essentlal group. The window of beneficial concentration for both of these elements is rather narrow, and a few parts per million in either direction from the optimum will produce either toxicity or deficiency symptoms. Selenium is a good example of the narrou: optirrial range of a toxic required element. At $0.1 \mathrm{ppm}$ (dry weight) in the aiet, nutritional needs are met in grazing sheep and sattle (Underwood, 1971). Intake of more 
TABLE 10. The oral LD 50 values for eight toxic elements in small mammals. ${ }^{a}$

\begin{tabular}{lcc}
\hline Element & $\begin{array}{c}\text { Oral LD } 50 \\
(\mathrm{mg} / \mathrm{kg})\end{array}$ & Animal \\
\hline Arsenic & $1-25$ & Kat \\
Cadmium & 72 & Kat \\
Chromium & 1870 & Kat \\
Nickel & 2000 & Rat \\
Lead & 150 & Rat \\
Selenium & 6 & Rat \\
Uranium & 400 & Muuse \\
Vanadium & 23 & Rat
\end{tabular}

${ }^{a_{\text {From N}}}$ National Research Council (1972), (1974a), (1974b), (1975), (1977); Environmental Protection Agency (1977); Maynard and Hodge (1949); and Nraigu (1980).

TABLE 11. Metallic emissions in 1970 (Dulka and Risby, 1976).

\begin{tabular}{lcc} 
Element & Tons per year & $\begin{array}{c}\text { Percent of total } \\
\text { metallic emissions }\end{array}$ \\
\hline Arsenic & 10,600 & 1.6 \\
Cadmium & 2,160 & 0.3 \\
Chromium & 18,136 & 2.7 \\
Nickel & 7,310 & 1.1 \\
Lead & $16,563^{\mathrm{a}}$ & 34.7 \\
Selenium & $197,437^{\mathrm{b}}$ & 0.1 \\
Vanadium & 986 & 3.1
\end{tabular}

\footnotetext{
a Off highway use.

${ }^{b}$ Highway use.
} 


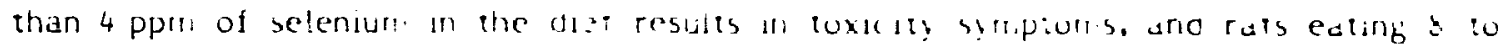

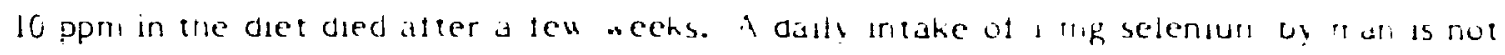

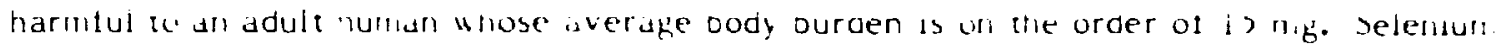
concentraion may be high in Western 1.b. gräins, Dut it is unlikely that a population subsisting on the output of fram from a selemiterous ares would obian a toxic dose under nomal dietary conditions. The thaxmum concentration of selerium that man can consume in the diet utthout roxk effects is between 3 dico 7 ppri ano ater contammin 0.5 ppri is dangerous (boues, 1466). The ormithg vater standard (Lavirormental

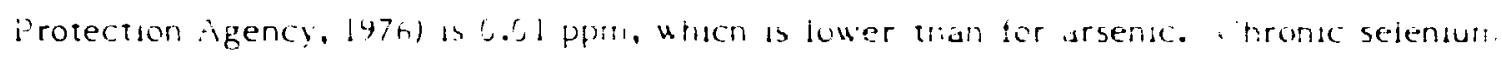

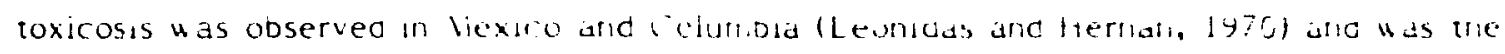

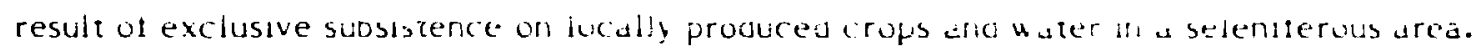

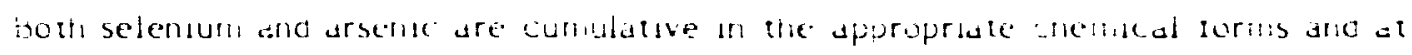

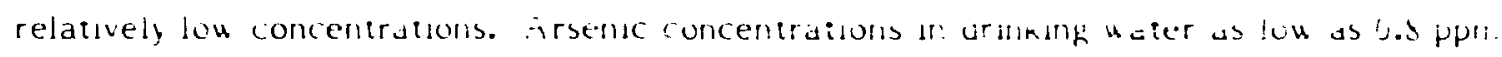

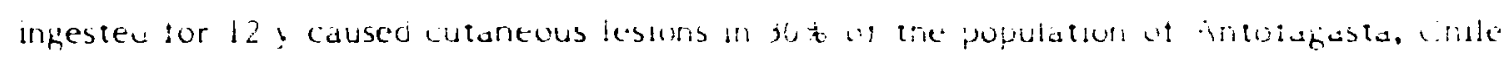
(Borgono and Greaber, 1971$)$. Lowen $(1+66)$ gives the prodade kethat cose ot arsenk lor

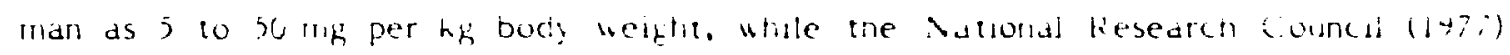

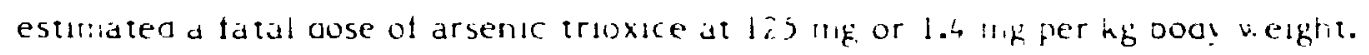

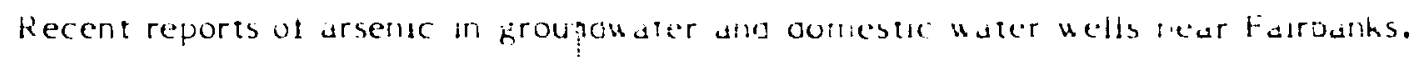

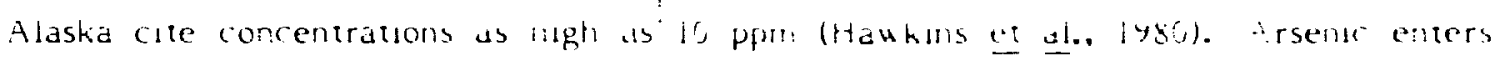

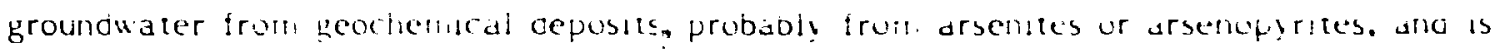

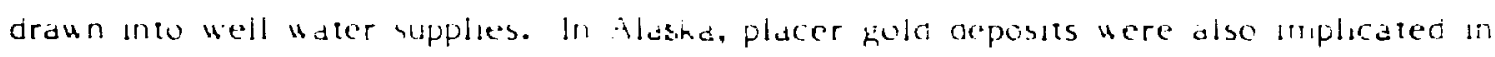

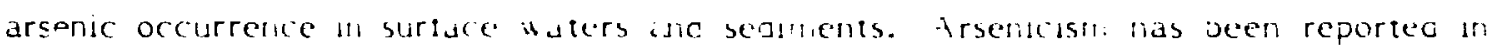

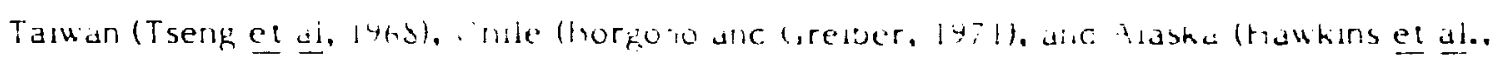

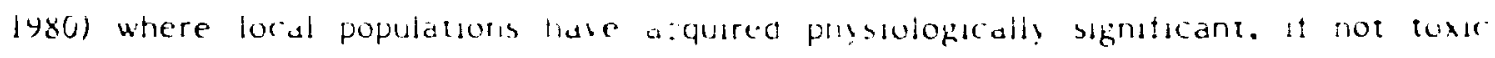
cuncentrations from drinkung udter.

Warine organisms also accumulate arsence trom the sed and shelitisin have rather

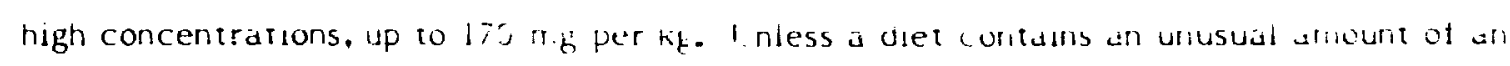
accumulator organism, however, exposure will de reghgiole. urganically oounc arsenc has a low toxicity and rats ted large anicun's al organs arsemir oro nut exhidit the usual toxicity symptoms (Coulson et al., 143)).

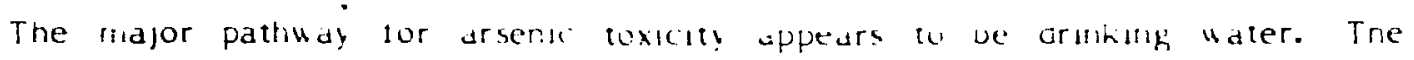

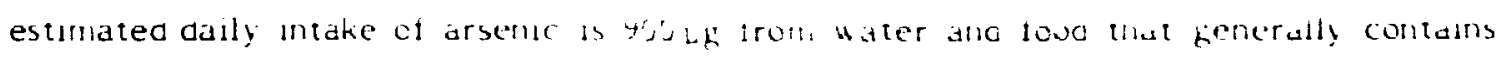

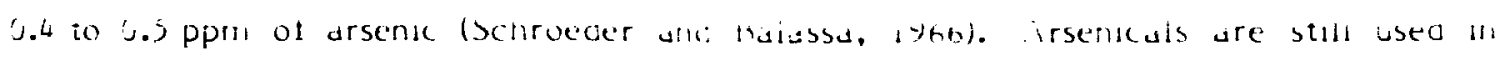

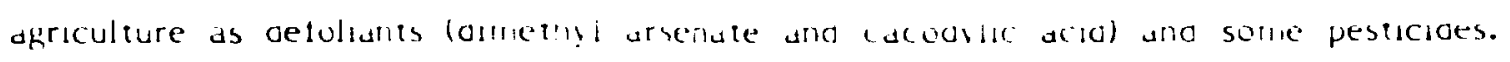

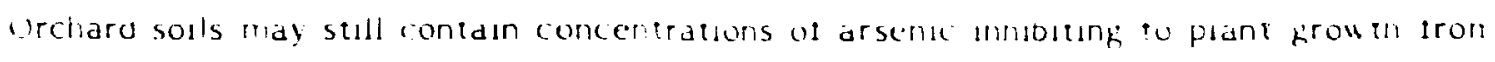

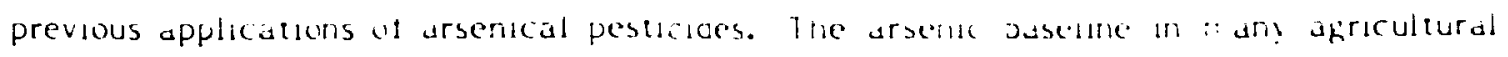


areas may thus de elevated above natural geocnemical levels trom the use of arsembals (Kuranca et al.. 1974). Jchroeder and halassa (1966) protide a revien of llie bellatior of arsentc in man and the pathuays by which it reaches ham.

The remaining tho essential elemients, chromium and nichel, are of relatively lou

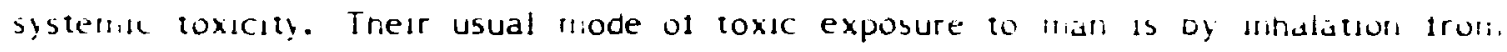
moustrial uses. Somie aermatological elfecis are observed trom wearirig nichet able

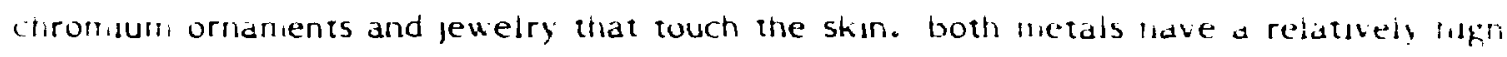
crustal abundance and may be tound in tood urganismis in muderately miti concentratjons. Apparently. mammals nave adapteo to relatively high juetary mahe ul these fretals decause their gastromtestinal sensitulty is lou. Chronilum is acculiuliteo by aquatic organisms and is also present in high concentrations (SCCC ppm) in the stute o1 elements dicurring in serpentmite and the deriveo solls. Vegetation erideriat is serpentirite areas is often unique because of ts taxonomy ano the linh inetal concentrations $1 \mathrm{c}$ contains. The typical oxidation state of the element uccurring in surficial muneral materials $\left(\mathrm{Cr}^{+3}\right)$ is not signaficantiy toxic.

Mickel may be taken up from the soll in relatively high cuncentrations by planis (to 4 ppril and in general occurs at higher concentrations in tood niaterials than oues chromuti. The tho metals therefore have contrastung ecological behavior, nichel deinf easily assirilated into the terrestral fouo chain ano chronilum being accumulated oy uquatic organisms. Nickel is also one of the more prominent contamunants in phiosphatuc iertilizers (106 ppm) Dut, decause of lts low gastromtestinal tract aosorption, liuy not present serious prodemis in agricultura! use.

The remaining tour elements, uhich are toxic, honessential elements, Hab De considered as two eleritent pairs because of their usual occurrence: lead and caonium, ano vanadium, ano uranium. Lead, cadmium, and zinc are of ten found together in polymetallic sulfide deposits. Ure bodies of lead may elevate local levels in soils and to a lumiteo extent, in surface water and groundwater. It can enter food chains at levels that may de toxic to mammals.

The soil-plant absorption pathway for lead is not particularly effective in the transfer of the element to mammals (Sharma and shupe, 1977). Therefore ledo is selaom transferred in large amounts from soil or substratum sources, although some such examples are present ( Lag and bolviken, 1974).

The deposition of lead particulates from industrial and automotive sources bypasses the soll-root pathway (Hirao and Patterson, 1974), and plants and anmals acquire lead burdens from atmospheric sources rather than from the substratum. Needies of conifers growing in the san Bernardino Forest in Southern California show an increase from 1 to 
3 ppm lead in the inst-year needes to 38 ppri in third-year needles, presumably from the same atmospheric sources that deliver oxidants to the forest from the Los Angeles basin (Coyne and bingliari., 1977). Lead is often bound or chelated in the numus layer of soils by organic colioıds and usually exhıbits maxinum concentration a few centimeters from the soil surface.

Cadmium is found at low geochemical levels and typical sources in most humar. ecological stuations are trom uater (pipes), food, tobacco, and airborne particulates. Cadminin is knowri to occur in elevated concentrations in some areas tromi endemic geochenucal sources, ats in the salinas lalley of Calitorna (burau et al.. 1980). Cadmium aiso occurs as a contäninant in phosphate fertilizers at 92 ppiri (Table 6) and was founo in phosplate ore at $\$ l$ ppm. Gadmium, has been identifled as the causal agent in the contamination ot a human 100 chain un Japan where the "Ital-1tal" disease was proqucea in. a locul population ut isherman trom the outiall of camium and other metals trom a mine and factury (kudayastu, 1971 ).

I. ramim anc vanadium typically do not exert toxic eftects on man from. geocnemical sources and ecological patmays. Vanacium alla uranium uten occur togetrier in several rock types and as shoun in Table b are present in rather nigh concentrations in phosphituc tertilizers cerivea trom phospliorite ures. suspenaed seaments in the Colorado kiver at Cibola, Delou biythe, contan sus ppri of vanaumu, but showed unly geocherrical levels uf uraniurr. The revien of vanadiun in olology and physlolug! by Schrueder es al. (1963) summarized the data on this relatively common elemerit in the farth's crust. Iandalunt reaches man in modest anounts that are, however, larger inan several required elements. Iandium has a lou gastromtestinal roxicity. It is present in plant ols, coal, and petroleum, proaucts, all of which have commion origins. It plays a small role in human physiology in lipid nietabolismi and seems to undergo some level of noneostatic regulation. Its role in human nietabolism has not been clearly delinea although severiti functions oi the metal have been demonstratea. Apparently vanadium does not tullill all of the previousl alscussed criteria for essentiality and therefore generally is not considered to be an essential trace elenient; although in a recent discussion by Vertz ( 1901$)$, vanaulum was considered in essential element. Its role in marıne invertebrate pnysiolog: (ascidian) in the body tiuic pigment, ier ovanacin, is unique and dcacincally interesting. The nigh levels in the marine atif al are apparently derived from the marine sedments in which it lives ano consumes. 
Uranium is generally widely dispersed in rock and soil types and is found at 1 to y ppm in most surface soil materials. In the Imperial Valley, 37 surtace soil samples were analyzed by neutron activation analysis and the inean soil uranium content was $2.9 \pm 0.3 \mathrm{ppm}$. Plant uptake is not particularly effective for uranium but may increase under alkaline conditions.

both uranium and vanadium occur in treble phosphate tertilizers (Table 6). I his anthropic source of uranium is probably the most common pathway to man, except tor drinking water. Uranium shows low gastrointestinal tract absorption ( $1 \%$ ) (Hursh et al.., 1969) and the gut pathway may not be particularly significant in the daily intake.

Actinides that are bound to organic matter may show larger uptake coefticients than the inorganic species of uranium in fresh water, and this pathway midy be more efficacious than previously believed (Watters et al., 1980).

Table 12 contains the elemental concentrations of the eignt toxic elements in mammalian organs. These data indicate the general location of physiological pools of the elements and thus, conform to the concept of a target organ for the element.

H.e have reviewed thus far the basic characteristics of the eight geotoxic elements, aescribed their geochemical disposition, and discussed some aspects of their biological and ecological interactions. The presence of natural deposits of these elements in the surface environment constitutes a source of persistent and of ten readily niobilized hazardous materials to man. Inweathered geological materials niay be niuch rrore available for transport and aissolution than weathered surtace minerals that are often in nontoxic valence states. The lact that only three of these eight elements (arsenic, selenium, and lead) under natural conditions have caused observable toxic reactions in animals and man can be related to the geochemical occurrence, chenical state, and to inefticient pathways to man for the remaining elements. All of the elenients have exhibited toxicity in industrial or laboratory conditions, and exposure to six of the elements has caused carcinogenic effects in occupational groups.

\section{DEVELOPMENT OF THE TOXICITY MATRIX}

The basic characteristics of toxicity are related to the effects of the elenent at the cellular and biochemical level. These effects are complex and may vary considerably with dosage, physiological state of the affected organism, and the presence of other elements and compounds (Vallee and Ulmer, 1972; Eichhorn, 1978). Synergism and antagonisin occur between such element pairs as cadmium and zinc, arsenic and selenium, 
TABLE 12. Elemental concentrations of eight elements in mammalian organs (Bowen, 1966).

\begin{tabular}{llllll} 
& \multicolumn{5}{c}{ Parts per million in organs } \\
\cline { 2 - 5 } Element & Brain & Heart & Kidney & Liver & Muscle \\
\hline Arsenic & 0.08 & 0.01 & 0.34 & 0.5 & 0.16 \\
Cadmium & 3 & 0.05 & 130 & 6.7 & 0.06 \\
Chromium & 0.12 & 0.02 & 0.05 & 0.02 & 0.04 \\
Nickel & 0.3 & 0.2 & 0.2 & 0.2 & 0.068 \\
Lead & 0.24 & 0.2 & 4.5 & 4.8 & 0.2 \\
Selenium & 2.1 & 0.7 & 2.1 & 2.1 & 2.5 \\
Lranium &.-- & 0.03 & 0.03 & 0.04 & 0.03 \\
Vanadium & 0.03 & 0.04 & 0.05 & 0.04 & 0.04 \\
- & & & & & \\
\hline
\end{tabular}

nıckel and iron, and vanadium and phosphorus. The level of calcium may affect all of the elements being discussed. These effects are too detailed and variable tor this discussıon and only those toxicity effects operating at the organism level will be utilized nere.

$A$ series of toxicity parameters have been compiled from the literature concerned with the eight toxic trace elements. Table 13 lists these parameters $u, t$ th the values tor each element of interest. The data on average crustal abundance and soil concentrations of the eight elements indicate their basic geochemical and ecological importance and are not weighted heavily in the toxicity evaluation. It is interesting, however, to note that for many elements, natural soil concentrations can be in the toxic range, and it is obvious that other factors besides the geochemical and ecological occurrence determine the hazard of toxic elements. Drinking water and continuous irrigation water standaras are indices of the toxic potential of the element as perceived by regulatory agencies (Environmental Protection Agency, 1976), and are usually based on the lower threshold of toxic responses. The average daily intake and the related body burden of the element are essentially the background physlological levels of the elernent above which toxicity occurs (Table 14). For some elements, the difference between average dasly intake, essentialıty. and the lower threshold toxic resporise is rather small. For example, selenium has a $3.2 \mathrm{rg} / \mathrm{d}$ average intake, an essentualıty level of 0.04 to $0.1 \mathrm{ppm}$, and a lower threshold tox:c response of 0.7 to $7 \mathrm{mg} / \mathrm{d}$. 
TABLE 13. Toxicity parameters for eight toxic metals.

\begin{tabular}{|c|c|c|c|c|c|c|c|c|c|c|}
\hline Element & $\begin{array}{l}\mathrm{ACA}^{\mathrm{a}} \\
(\mathrm{ppm})\end{array}$ & $\begin{array}{l}\text { Soil b } \\
\text { (ppm) }\end{array}$ & $\begin{array}{l}\text { DWs } \\
\text { (ug/liter) }\end{array}$ & $\begin{array}{l}\text { IRR } \\
\mathrm{HHO}^{\mathrm{d}} \\
\text { ( } \mathrm{g} / \text { /liter) }\end{array}$ & $\begin{array}{l}\text { Daily } \\
\text { mtake } \\
(\mu g)\end{array}$ & $\begin{array}{l}\text { Aquatic } \\
\text { toxicity } \\
\text { (mb/liter) }\end{array}$ & $\begin{array}{l}\text { Plant } \\
\text { toxicity } \\
\text { (pprm) }\end{array}$ & $\begin{array}{l}\text { Mammahan } \\
\text { toxicity }\end{array}$ & $\begin{array}{l}\text { Human } \\
\text { toxicity }\end{array}$ & $\begin{array}{l}\text { FISH } \\
\text { BIOAC:C1) }\end{array}$ \\
\hline Arsenic & 1.8 & 6 & 0.05 & 0.1 & 900 & 0.02 & $0.5-2$ & $\begin{array}{l}11.2 \mathrm{Ppm} \\
1-25 \mathrm{mIg} / \mathrm{kg}\end{array}$ & $\begin{array}{l}125 \mathrm{mg} \\
0.06-1.18 \mathrm{mg} / \mathrm{kg}\end{array}$ & 333 \\
\hline Cadmium & 0.2 & 0.06 & 0.01 & 0.01 & 72 & $0.01-10$ & $0.1-3$ & $72 \mathrm{mg} / \mathrm{kg}$ & $3 \mathrm{mg} / \mathrm{d}$ & 200 \\
\hline Chromium & 100 & 100 & 0.05 & 0.1 & 284 & $0.03-64$ & $0.5-24$ & $1870 \mathrm{rmg} / \mathrm{kg}$ & 4000 ppm & 4000 \\
\hline Nickel & 75 & 40 & 0.05 & 0.2 & 500 & 0.03 & $25-100$ & $1-3 \mathrm{~g} / \mathrm{kg}$ & --8 & 100 \\
\hline Lead & 13 & 10 & 0.05 & 0.1 & 300 & $0.01-50$ & $25-30$ & $0.5-0.8 \mathrm{ppm}$ & $1.7 \mathrm{mg} / \mathrm{kg}$ & 300 \\
\hline Selenium & 0.05 & 0.2 & 0.01 & 0.02 & 200 & 2 & $5-20$ & $6 \mathrm{mg} / \mathrm{kg}$ & $0.7-7 \mathrm{mg} / \mathrm{d}$ & 167 \\
\hline Uranium & 1.8 & 1 & 0.1 & 0.5 & 1.3 & 2.8 & $s c+$ & $400 \mathrm{~m} 1 \mathrm{~g} / \mathrm{kg}$ & $1-4$ th diet & 10 \\
\hline Vanadiuns & 135 & 100 & 0.1 & 0.1 & 1160 & 4.8 & $10-40$ & so $11 \mathrm{~g} / \mathrm{kg}$ & not known & 10 \\
\hline
\end{tabular}

\footnotetext{
${ }^{\text {a }}$ Average crustal abundance.
}

${ }^{b}$ Average soil concentration.

CDrinking water standard.

dContinuous irrigation water standard.

Eaily intake from food, air, and water.

f Bioaccumulation factor for fishes.

g Toxic only as the carbonyl; somle cutaneous sensitivity. 
TARLE 14. Estimated daily intake of elements from foods

(Mahaffey et al., 1975).

\begin{tabular}{|c|c|c|c|c|}
\hline Food type & $\begin{array}{l}\text { Lead } \\
(\mu g / d)\end{array}$ & $\begin{array}{l}\text { Cadmium } \\
(\mu \mathrm{g} / \mathrm{d})\end{array}$ & $\begin{array}{c}\text { Arsenic } \\
(\mu \mathrm{g} / \mathrm{d})\end{array}$ & $\begin{array}{l}\text { Seleniurn } \\
\qquad(\mu \mathrm{g} / \mathrm{d})\end{array}$ \\
\hline Daıry products & -- & 3.94 & 2.34 & -- \\
\hline Meat, fish, poultry & 4 & 2.49 & 5.64 & 56.3 \\
\hline Grāın, cereal & 4.16 & 11.66 & 1.35 & 92.5 \\
\hline Potatoes & 0.7 & 9.11 & 0.64 & 0.65 \\
\hline Leafy vegetäbles & $3.0,3$ & 3.18 & -- & -- \\
\hline Legumes & 18.08 & 0.42 & -- & -- \\
\hline Koot vegetables & 3.83 & 0.76 & -- & 0.25 \\
\hline Fruits, garden & 11.36 & 1.71 & -- & -- \\
\hline Fruits, orchard & 9.49 & 9.38 & -- & -- \\
\hline vil and fats & 0.67 & 1.36 & 0.17 & -- \\
\hline sugar & 0.55 & 0.68 & -- & -- \\
\hline Beverages & 3.81 & 6.49 & $-=$ & $-=$ \\
\hline TOTAL & 60.4 & 51.2 & 10.1 & 149.7 \\
\hline \multirow[t]{3}{*}{ Major contributors } & Leggumes & Grain & Neat & Meat \\
\hline & Fruits & Potatoes & Dairy & Grain \\
\hline & Grain & Fruits & Grain & \\
\hline
\end{tabular}

Aquatic animal, plant, and mammalian toxicities are those determined in laboratory or test plot experimentc. In some cases a relatively broad range of toxic response is reported because of ditterences in organism response, elemental form, and mode of exposure. strong differences are seen between oral, intramuscular, intraperitoneal, and intravenous methods of exposure. The data in Table 13 are confined to oral exposures that would simulate intake by typical ecological pathways. The ecological sources and common exposure modes are the usual routes by which organisms, including man, acquire their daily intake and body Durdens (Shacklette et al., 1978).

The bioaccumulation factor for fish "as obtained from the report on environmental, health, and control aspects of coal conversion (Braunstein et al., 1977). Other data on the subject may be obtained from Environmental Protection Agency (1977), where values for minimum acute toxicity concentrations and estimated permissible concentrations for various ecological media are given. 
In Table 15, the eight elements are ranked according to their inherent toxic.ty on the basis of the eight toxicity parameters, with weight given to the peripheral parameters of crustal abundance, soil concentrations, and exposure modes. ()nly the elements occurring in the upper two ranks were given a toxicity value or point. Lijanium did not occur in the upper two ranks in any parameter and, along with vanadium, occurred generally in the lower portion of the matrix.

The ranking of the elements from high to low toxicity on the basis of ten parameters is as follows.
(1) Arsenic
(2) Cadmium
(3) Lead
(4) Selenium
(5) Nickel
(6) Vanadiumi
(7) Chromium
(8) Uranium

Vanadium and chromium occurred in the upper two ranks only once. Vanadium did so because of its high crustal abundance, which is not as significant as the paraneter for which chromium was scored (soil concentration). Nickel is ranked above chromium because greater weight is given to the plant toxicity and uptake of nickel than the bioaccumulation toxicity for fish of chromium. This was done because more plant foods than fish occur in the average diet (International Commission on Radiological Protection, 1975; Rupp et al.. 1980). The differences between elements in the lower categories of the toxicity natrix are probably small.

The primary routes by which nickel, chromium, and vanadium exposures to man occur are industrial and occupational. It is unlikely that, as the result of typical ecological transport phenomena, there would be toxic exposures of these three elements to man. Nickel and chromium may occur in high concentration in serpentinite-derived soils, but usually the presence of the metals is self-limiting because the resulting phytotoxicity of the soil reduces or eliminates the trophic transfer of the endemically high metal concentrations characteristic of the serpentinite soil and rock.

Assessment of the geochemical, ecological, and toxicity parameters of eight potentially toxic elements has resulted in a toxicity ranking of the elements. The validity of the ranking is demonstrated by the occurrence of toxic episodes and studies of subtoxic effects of the elements. The occurrence of four cases of arsenicism from high exposures from groundwater or other potable water supplies demonstrates the element's toxic potential. 
TABLE 15. Toxicity matrix.

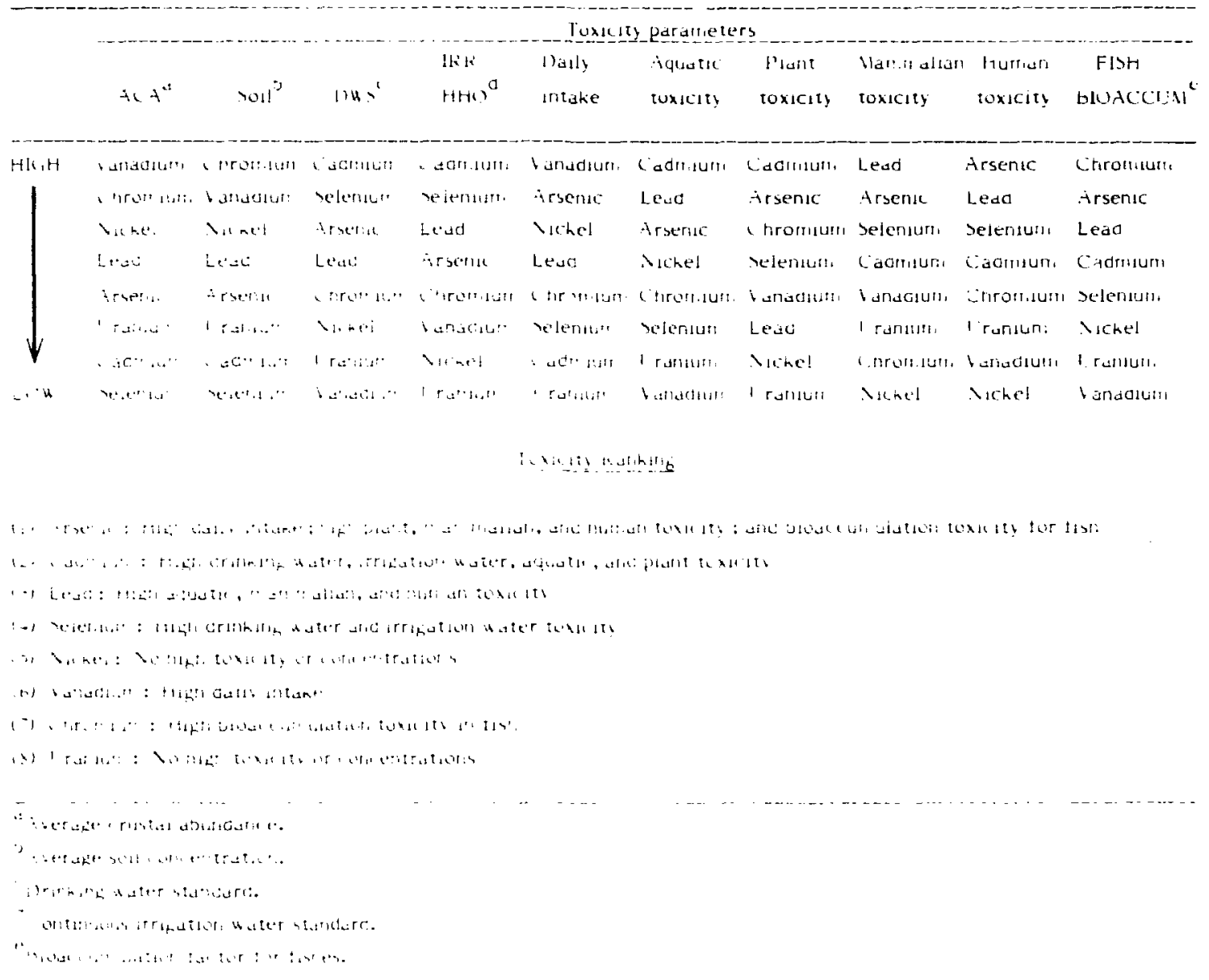


Cadmium from ecological exposures has been implicated in essential hypertension and other cardiovascular diseases in the general population. The industrial exposure of a Japanese population to cadmium via their aquatic lood chan is well documentud (Kobayashi, 1978). The high levels of lead in children in cities and in the urban population in general from air particulates and in the general population from processed (canned) food (Settle and Patterson, 1980) also attest to the widespread exposure to this toxic element.

Selenium is geochemically the least abundant of the elements considered but has a high potential for accumulation in vegetation, especially small grains grown in the Western 13.S. Otganically complexed selenium is relatively more toxic to mammals in this form, in contrast to arsenic, but this source is apparently effectively diluted in the cosmopolitan origin of the average diet. The only known human toxic exposure to selenium occurred in Mexico and South America where a high rate of ingestion of locally grown foods was related to the intoxication. The toxic and lethal exposures of range cattle to selenium have been frequently described and the specific accumulator plant species identified. If the range animal consumes vegetation with a selenium concentration of 100 to $1000 \mathrm{ppm}$, the total diet easily reaches the toxic level of 4 to 7 ppm, even though the accumulator plants constitute a fraction of its food intake.

Naturally occurring nickel, chromium, vanadium, and uranium seldom reach man or animals in concentrations that will induce toxic symptoms, primarily because of the low: levels of gastrointestinal uptake. Although these elements occur in groundwater and surface water, the elemental form is nontoxic and the concentrations coupled with the low gastrointestinal uptake are generally insufficient to cause systemic effects.

Despite the large deposits of toxic elements present in the surficial environment, especially arsenic, cadmium, lead, and selenium, th. occurrence of toxic events has been relatively rare. When they do occur, they are relatively easy to diagnose and rectify. Modern methods of elemental analysis, especially water analysis, have provided the biogeochemist with effective tools in detecting elevated levels of anthropic and naturally occurring elements and compounds.

The behavior of man-deposited toxic substances in the surficial environment may be reasonably predicted from the tehavior of naturally occurring toxic elements. When the dominant elements composing the toxic substances are known, elemental behavior may be assumed to be analogous with elements already present in the geological medium chosen for a disposal. Baseline geochemical reconnaissance and analyses can be a useful component of any siting study related to waste and hazardous material disposal. 
Natural concentrations of certain elements may provide a significant role in localization of mobile substances in a waste material. Bentonite and other alumino-silicates have high complexation potential for elements released into the deposit. Carbonates, sulfide deposits, and other types of ore bodies should be systematically investigated for their ability to play a useful role in hazardous waste repositories.

\section{SUMMARY}

The geologic disposal of radioactive and other hazardous waste does not present a new or unique problem. Toxic materials have been incorporated in the Earth's crust by man or nature during the history of the planet. Ijseful insights on the biological effects of geotoxic materials can be gained from a study of their natural abundance and transport. For this purpose, the current review of the existing data has been initiated to provide a resource for future study.

This report provides a basis for evaluating the problem and identifying useful areas for continued investigation. Such study can provide information for

- a perspective on the severity of problems resulting from underground burial of hazardous waste,

- improved understanding of transport processes of toxic materials,

- development of an overview on siting radioactive and hazardous waste repositories in areas of high natural geotoxicity, and

- improved understanding of geochemistry in health and disease.

From this preliminary study, it is concluded that the following are the most useful areas for future study.

- Transport of stable element analogs of biologically significant radionuclides in nuclear waste.

- Impacts resulting from naturally occurring geotoxic materials with the most biologically serious consequences. These include arsenic, cadmium, lead, and selenium.

Extensive information exists in the current literature relative to the required study. Future work should be focused on accumulating and systematically organizing the data so that it may be readily appiied to problems involving geotoxic materials in the surficial geological environment. 


\section{ACKNOH LEDGNENTS}

We would like to acknowledge a report by Dr. Arthur Furst and Wrs. Ingeborg Harding-Barlow of the Institute of Chemical Biology, Iniversity of Jan Francisco, on the toxicity of mineral deposits. Information on the chenical biology of the elements discussed was extracted from their report and included in this review. 
Andreae, M. O. (1978), Distribution and speciation of arsenic in natural waters and some marine algae, Deep-Sea Res. 25, 291 -402.

Baptist, J. P., and C. W. Lewis (1969), Transfer of ${ }^{65} \mathrm{In}$ and ${ }^{51} \mathrm{Cr}$ through an estuarine food chain, in Proc. 2nd National Symp. Radioecology (1j.S. Atomic Energy Commission, Washington, DC, Conf. \# 670503), Pp. 420-430.

Borgono, J. W., and R. Greiber (1971), Epidemiological study of arsenicism in the city of Antofagasta, in Trace Elements in Environmental Health, D. V. Hemphill, Ed. (1jniversity of Missouri, Columbia, M(J), vol. V, PP. 13-24.

Bouwer, E. J., and J. W. McKloveen (1978), Uranium assay of phosphate fertilizers and

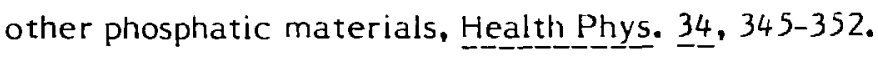

Bowen, H. J. 11. (1966), Trace Elements in Biochemistry (Academic Press, New York).

Boyle, R. H., and I. R. Jonasson (1973), The geochemistry of arsenic and its use as an indicator element in geochemical prosperting, J. Geochem. Explor. 2(3), 251-296.

Braunstein, H. M., E. D. Copehaver, and H. A. Pfuderer, Eas. (1977), Environmental, Health and Control Aspects of Coal Conversion: An Information Uverview, Vati Kidge National Laboratory, Mak Ridge, TN, ORNL/EIS-45, vol. 2.

Burau, R., W. Jopling, C. Martin, and G. Snow (1980), Monterey Babsin Pilot Mlonitor Report, Iniversity of California, Davis, CA, vol. Z.

Cannon, H. (1974), Natural toxicants of geological origin and their availability to man, in Environmental Quality and Food Supply, P. L. White and D. Robbins, tds. (Futura Publishing Co., Mt. Kisco, NY), Pp. 143-164.

Coulsori, E. J., R. E. Remington, and K. N. Lynch (1935), Netabolism in the rat of naturally occurring arsenic of shrimp as compared with arsenic trioxide, J._Nutr. $10,25$.

Coyne, P. I., and C. E. Bingham (1977), Carbon dioxide correlation with oxidant air pollution in the San Bernardino Mountains of California, ]. Air Pollut. Control Assoc. 27(8), 782-783. 
Duce, R. A., G. L. Hoffman, and W. H. Zoller (1975), Atmospheric trace metals at remote Northern and Southern Hemisphere sites: pollution or natural?, Science $1 \$ 7(4171)$, $59-61$.

Dulka, J. J., and T. H. Risby (1976), IJtratrace metals in some environmental and biological systems, Anal. Chem. 48, 640A-653A.

Eichhorn, G. L. (1978), Active sites of biological macromolecules and their interactiun with heavy metals, in Ecological Toxicity Research: Effects of Heavy Vletal and Organohaline Compounds, A. D. Mclntyre and C. F. Mills, Eds. (Plenum Press, Neu Ycrk), pp. $123-142$.

Environmental Protection Agency (1976), National Primary_Lrinking Water Regulations--1976, Environmental Protection Agency Office of Water Supply, washington, DC, EPA-570/9-76-003.

Environmental Protection Agency (1977), Multimedia Environmental Cioals tor Environmental Assessment, Environmental Protection Agency Uffice of Research and Development, Research Triangle Park, NC, EPA-600/7-77/136A, vols. 1 and 11.

Ferguson, J. F., and J. Gavis (1972), A review of the arsenic cycle in natural waters, Water Res. $6(11), 1259-1274$.

Fortescue, J. A. C. (1974), Landscape geochemistry and geoepidemiology in Irace Substances in Environmental Health, Proc. 8th Ann. Conf., Columbia, Wissouri, D. D. Hemphill, Ed.

Fruchter, J. S., D. E. Robertson, J. C. Evans, K. B. Olsen, E. A. Lepel, J. C. Laul, K. H. Abel, R. W. Sanders, P. O. Jackson, N. S. Wagman, R. W. Perkins, H. H. VanTuyl, R. H. Beauchamp, J. W. Shade, J. L. Daniel, R. L. Erikson, G. A. Sehmel, R. N. Lee, A. V. Robinson, O. R. Moss, J. K. Briant, and W. C. Cannon (1980), int. St. Helens ash from 18 May 1980 eruption: chemical, physical, minerological, and biological properties, Science $209,1116-1125$.

Gardiner, J. (1974), The chemistry of cadmium in natural water, part 1--a study of cadmium complex formation using the cadmium specific-ion electrode, Water Res. $\underline{8}(1)$, 23-30. 


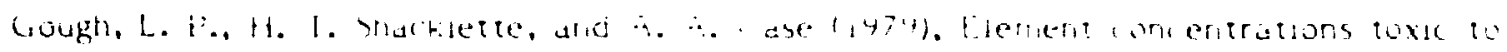

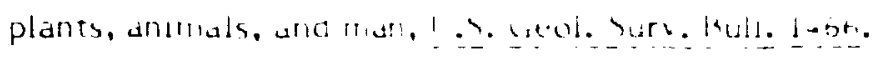

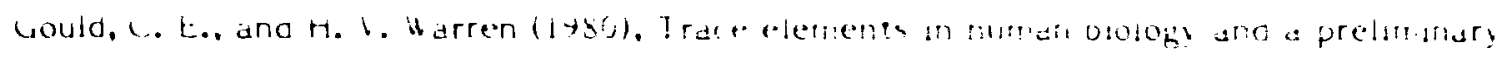

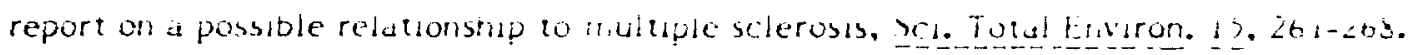

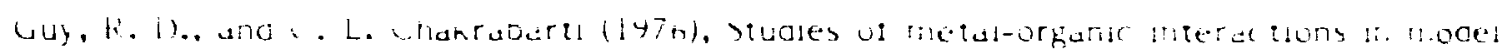

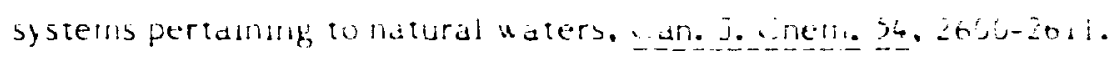

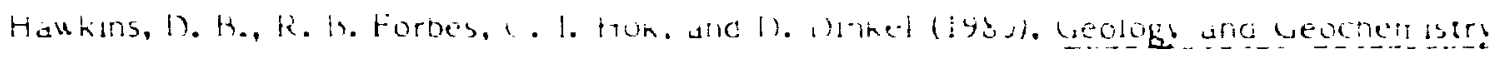

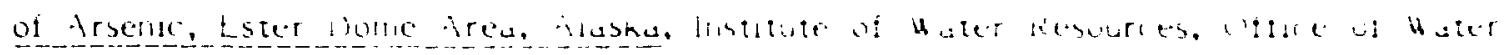

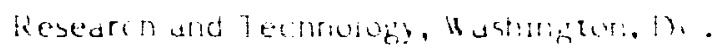

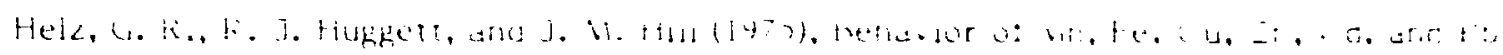

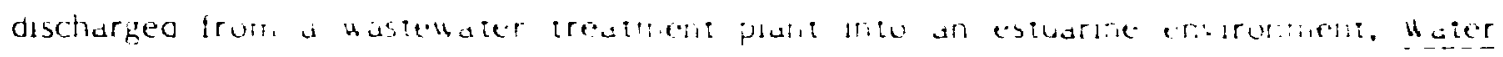
ies. $9.631-636$.

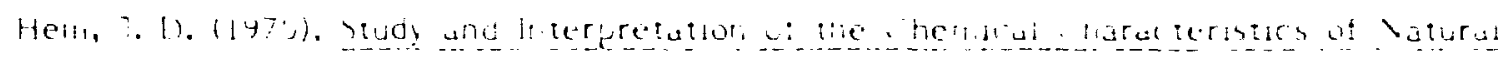

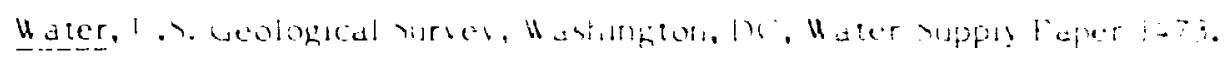

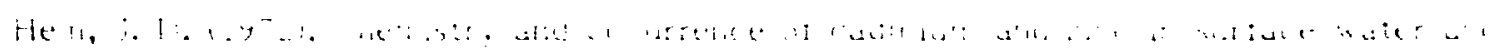

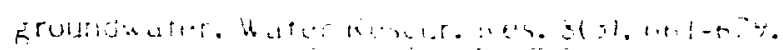

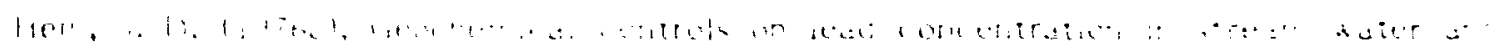

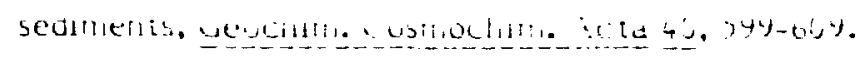

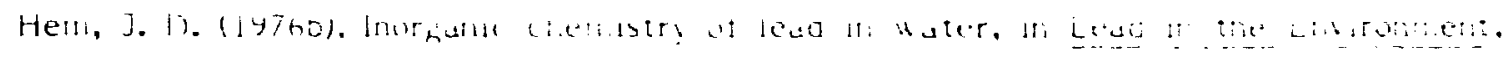

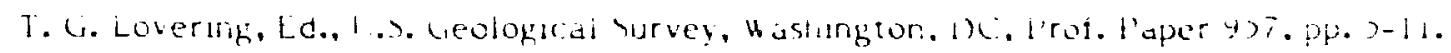

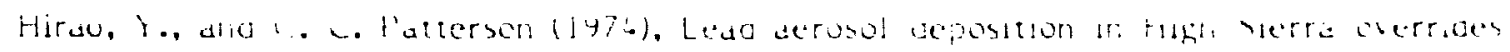

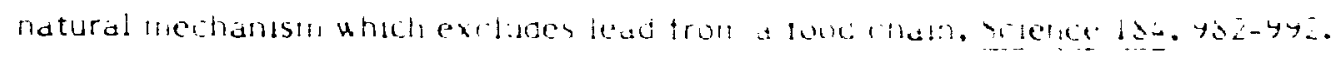

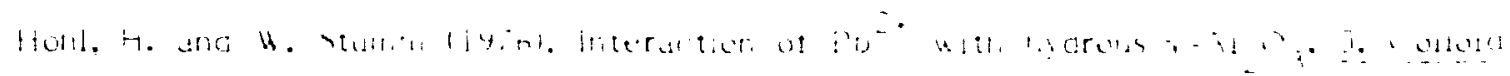
Intertace $10,2 x+2,21-29$.

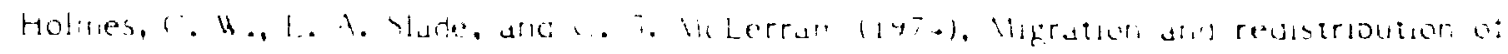

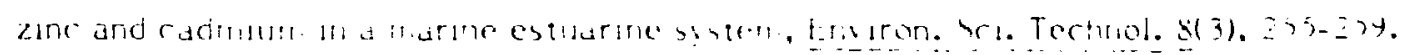


Hophins. L. L.. Tr., and H. L. Mohr (1971). The blologlcal essentialit! d vanadunt, in Veuer Trace Elenents in Vutration. W. Vert? and H. E. Cornatzer. L.ds. Marcel Kehter. veu rork). pp. 145-?19.

Huang. C. P., H. A. Elliott, and K. U. Ashmiead (1977). Iriterfacial reactions and the fate of heavy metals in salt water systemis. J. Hater Poliut. Control Fed. 44(5). $745-75 \%$.

Hursh, J. H., W. R. Neuman, T. Toribarä, H. Uilson, and C. Haterhouse (lygy), Wral ingestion of urariumi in man. Healtri phys. 17.619-621.

International Commission on Radiological Protection (1475), Report of the Task wroup_on Reierence Uan. 1475 (Pergamion Press, veu York), report 23, pp. 348-34y.

Ireland, K. (1ys(J), Chemical ecology investigations at The veysers, California, lieotherm. Kesour. Counc. Trans. 4, 675-678.

Jackison, K. J., 1.R. Jonasson, and G. H. Skippen (1978), The nature of metals-sedinent-water interactions in freshuater bodies, with emphasis on the role of organic riatter. Earth-ici. Rev. 14, 97-146.

Jenne. E. t. (1968), Controls on $\mathrm{Vn}, \mathrm{Fe}, \mathrm{Co}, \mathrm{Vi}, \mathrm{Cu}$, and $\mathrm{z}$ n concentrations $1 \mathrm{r}$ soils and water: the significant role of hydrous $\mathrm{Un}$ and Fe oxides, in Trace Organics in Water, $R$. A. Baker. Ed. (American (henical tociety, Washington, DC), p. 337.

Kharkar. D. F., K. K. Turekian, and K. K. Bertine (1968), Stream supply of dissolvea silver, molybdenum, antimiony, selenium, chromium, cobalt, rubidium, and cesium to the oceans, Geochim. Cosmochim. Acta 32. 285-29S.

Kinkade, H. L., and H. E. Erdman (1975), The influence of hardness coniponents $\mathrm{CCa}^{2+}$ and $\mathrm{Mg}^{2+}$ ) in water on the uptake and concentration of cadmium in a simulated freshwater ecosystem, Environ. Res. 10(2), 308-313.

Kobayashı, J. (1971), Relation betueen the "itai-itai" disease and the pollution of river

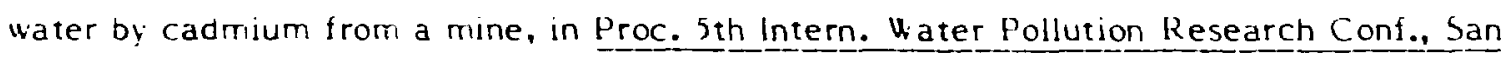
Francisco, Calıfornia (Pergamon Press, New York), pp. 1-25. 
Kobayashı, J. (1978), Pollution by Cadruuri, and the "ital-ital" disease in Japan, in Toxici:ies of Hedvy lletals in the Knvironment, F. W. Venne Ed. (Narcel Dekitier Inc.. veu rork), part I, pp. 1yy-260.

Koranda, J. J., N. Stuart, S. Thompson, and C. Conrado (197y), biogeochemical studies of Wintering Waterfowl in the Imperial and Sacramento Valleys, Laurence Livermore Laboratory, Livermore, CA, I.CID-1\$288.

Koranda, J. J., S. Thompson, and M. Stuart (1980), Trace elements in soils and sedments of the Imperial Valley, Californiä, Laurence Livermore National Laboratory. Livermore. CA, in preparation.

Koranda, J. J. (1480), Analyses of Wit. St. Helens ash, Energy Technol. Rev. Y., ZU-2L.

Kovalsky, V. V. (1974), Geochemical environment, health, and disease, in Trace Substances in Environmental Health, Proc. Ann. Conf., Ijniversity of Missouri, Colurnbla, Missouri, D. D. Hemphill, Ed., vol. III, pp. 137-142.

Krauskopf, K. U. (1455), Sedimentary deposits of rare metals, Econ. Leol. 5G(1), 411-46).

Krauskopf, K. G. (1967), Introduction to (ieochemistry (McGrau-Hill, Neu York).

Lag, J., and B. Bolviken (1974), Some naturally-poisoned areas of interest in prospecting. soil chemistry, and geomedicine, Nor. Leol. IJnders. (Publ.) 304, 73-96.

Langmuir, D. (1978), Uranium solution-mineral equilibria at low temperatures with applications to sedimentary ore deposits, Cieochim. Cosmochim. Acta 42 2 , 547-564.

Lee, G. F. (1975), Role of hydrous metal oxides in the transport of heavy hietals in the environment, in Heavy Metals in the Aguatic Environnent, P. A. Krentel, Lo. (Perbamon Fress, New York), p. 137.

Leonidas, II. C., and C. E. Hernan (1970), Ceneral study of soils-survey ol selentferous areas in a sector of the valley of the Guaguaqui River, Columbia cieogr. 1, 10y-1yl. 
Lu, P. Y., K. L. Wetcalf, K. Furman, K. Vogel, and J. Hassett (1y7), llogel ecosystem sivoles of lead and cadmumi and of urdan seudge sluage contammg thesc elememts. J. Environ. Sual. 4(4), 50)-50y.

Luckey, T.D. (IYSG), fiormesis w ith lonizıng Radidtion (C.K.C. Press, Inc., buca Katon, FL).

Wahatfey, K. K., P. E. Corneliussen, C. F. Jelinek, and T. A. Fiorina (1y7j), Heavy neta! exposure trom foods, Environ. Health Perspec. 12,63-ic.

Hason, th. (1966), Principles of Leochemistry (John Wiley S Sons, Inc.. Veu Vork).

llaynard, E. A., and H. C. Hodge (1944), studies of the toxicity of various uranlumi compounus when fed to experimental animals, in Pharmacology and Toxicolog: of Iranium Compounds, C. Voegtlin and H. C. Hodge, Eds. (Mcliraw Hill book Co., Nek rork). Pp. 309-376.

Merlini, M. and G. Pozzı (1977a), Lead and freshwater tishes, part i--lead accurnulation and water $\mathrm{pH}$, Environ. Pollut. 12(3), 167-17

Vlerlıni, M. and C. Pozzi (1977b), Lead and treshuater fishes, part Il--1onic lead accumulation, Environ. Pollut. 13(2), 119-126.

Nertz, W. (1981). The essential trace elements, Sclence 213, $1332-1338$.

Namminga, H., and J. Wilhm (1977), Heavy metals in water, sediments, and chironoumas, J. Water Pollut. Control Fed. 49(7), 1725-1731.

National Research Council (1972), Lead. Airborne_Lead in Perspective, Cominittee on Biologic Effects of Atmospheric Pollutants, National Academy of Sciences, Washington, DC.

National Research Council (1974a), Chromium, Committee on Biologic Etfects of Atmospheric Pollutants, National Academy of Sciences, Washington, DC.

National Research Council (1974b), Vanadium, Committee on Biologic Effects of Atmospheric Pollutants, National Academy of sciences, Washington, DC. 
National Research Counc1l (1975), Nickel, Committee on Biologic Effects of Atmospheric Poliutants, National Academy of sciences, 4 ashington, $D C$.

Natıonal Research Council (1977), Arsenic, Committee on Biologic Effects of Atmospheric Pollution, National Academy of Sciences, Hashington, DC.

\raigu, J. 0. (1986), Cadmium in the Environment, Part 11. Toxicology, (John Wiley and Jons, New York).

O'shea, T. .., and K. H. Niancy (1978), The effect of $\mathrm{pH}$ and hardness on the competitive interaction between trace metals ions and inorganic and organic complexing agents tound

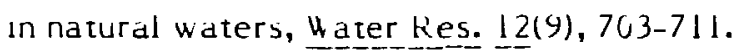

Ssweiler, G. D., and U. A. Vancielder (1978), Epidemiology of lead poisoning in animals, in Toxicology of Heavy Metals in the Environment, F. H. Nehme, Ed. Marcel Dekker Inc., New York), part I, pp. 143-171.

Patrick, F. M., and M. Loutit (1976), Passage of metals in elfluents, through bacteria to higher organismis, Later Res. IU(4), 333-335.

Patterson, J. H., H. [. Allen, and J. J. Scala (1977), Carbonate precipitation for heavy metal pollutants, J. Uater Pollut. Control Fed. 49(12), 23y7-2410.

Perhac, R. H. (1972), Distribution of C. Co, Cu, Fe, Mn, Ni, Pb, and In in dissolved and particulate solids from two streams in Tennessee, J. Hydrol. 15(3), 177-186.

Perhac, R. M. (1974a), Water Transport of Heavy Wetals in Jolution and by Different sizes of Particulate Solids, Iniversity of Tennessee Water Resources Research Cienter, Knoxville, TN.

Pernac, R. H. (1974b), Heavy Netal 1)istribution in Bottom Sedments and Hastes in the Tennessee River-Loudon Lake Keservation System, Lniversity of Tennessee $\mathbb{H a t e r}$ Resources kesearch Center, Knoxville, Tiv, Report $4 \mathrm{U}$.

Phelps, D. K., G. Telek, and R. L. Lapan, Jr. (197)), Evaluation of the distribution of heavy rretals in the food chain, Ing. Ambientale 4(3), 321-32s. 
Pimental, K. D., R. R. Ireland, and G. A. Tompkins (1978), Chemical tingerprınts to ussess the effects of geothermal development on water quality in Imperial Valley, Leotherm. kiesour. Counc. Trans. 2, 527-530.

Poldervaart, A., Ed. (1955), Crust of the Earth, Geological society ol America, Boulaer. CO, Paper 62.

Poole, C., and L. E. Smythe (1980), Blood levels in Papua New Luinea children living in a remote area, Sci. Total Environ. 15, 17-24.

Ramamoorthy, S., and D. J. Kushner (1975), Heavy metal binding components of river water, J.Fish. Res. Board Can. 32(10), 1755-1766.

Ramamoorthy, S., and B. R. Rust (1978), Heavy metal exchange processes in sediment-water systems, Environ. Geol. 2, 165-172.

Rankama, K., and T. G. Sahama (1950), Geochemistry (1)niversity of Chıcago Press, Chicago).

Rashid, W. A. (1974), Absorption of metals on sedimentary and peat humic acids, Chem. Geol. 13 $3(2), 115-123$.

Kashid, M. A., and J. U. Leonard (1973), Modifications in the solubility and precipitation behavior of various metals as a result of their interaction with sedimentary numic acıo. Chem. Geol. $11(2), 89-97$.

Reay, P. F. (1972), The accumulation of arsenic trom arsenic-rich natural waters by aquatic plants, ]. Appl. Ecol. 9(2), 557-565.

Rehwoldt, R., D. Karimian-Teherani, and H. Altmann (1975), Measurement and distribution of various heavy metals in the Danube River and Danube Canal aquatic communities in the vicinity of Vienna, Austria, Sci. Total Environ. 3(4), 341-348.

Ronov, A. B., and A. A. Yaroshevsky (1969), Chemical composition of the Earth's crust, in The Earth's Crust and Upper Mantle, P. J. Hart, Ed., American Ceophysical Union, Washington, DC, Monograph 13, pp. 37-57. 
Rosenfeld, I., and O. A. Beath (1964), Seleniurn: Leobotany, Biochemistry, Toxicity, and Nutrition (Academic Press, New York).

Rupp, E. M., F. L. Miller, and C. F. Baes IIl (1980), Some results of recent surveys of fish and shellfish consumption by age and region of the U.S. residents, Health Phys. 39. 165-175.

Schroeder, D. C., and G. F. Lee (1975), Potential transformations of chromium in natura! waters, water, Air, Soil Pollut. 4(3/4), 355-365.

Schroeder, H. A., J. J. Balassa, and 1. H. Tipton (1963), Abnornal trace elements in man--vanadium, J.Chron. Dis. 16, 1047-1071.

schroeder, H. A., and J. J. balassa (1966), Abnormal trace elenients in man--arsenic, J. Chronic. Dis. $19,85-106$.

Settle, $1 . M .$, and $C . C$. Patterson (1980), Lead in albacore: guide to lead pollution in the Americas, science 207, 1167-1176.

Shacklette, H. T., J. A. Erdman, T. F. Harms, and C. S. E. Papp (1978), Trace elements ii plant foodstuffs, in Toxicty of Heavy Metals in the Environment, F. $u$. Uehme, Ed. (Narcel Lekiker Inc., New York), part 1, pp. 25-6\$.

Sharma, R. P. and J. L. Shupe (1977), Lead, cadmium, and arsenic residues in aninal tissues in relation to those in their surrounding habitat, Sci. Total Environ. 7, 53-62.

Shima, M. (1957), A new sublinate containing nickel, found in a fumarole of an active volcano, J. Sci. Res. Inst. Toyko 51, 11-14.

Soane, B. D. and D. H. Saunder (195y), Nickel and chromium toxicity of serpentine soils in southern Rhodesia, soil sci. 38. 322-33r.

Stewart, F. H. (1963), Marıne evaporites, in Mata of Ceochemistry, M. Fleisher, Ed., L.S. Geological survey, Washington, 1 C, Prot. Paper $440-1$.

suzuki, W., T. Yamata, T. Niyazaki, and K. Kawazoe $(1 y 7 y)$, sorption ana accumulation of cadmium in the sediment of the Tama River, Uater Res. 13(1), 57-63. 


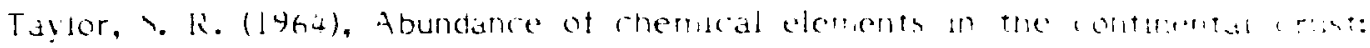

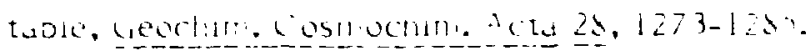

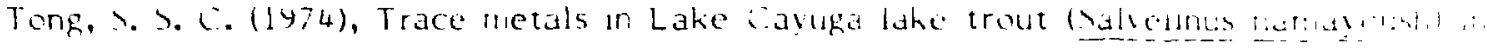
re'ation to age. J. Fisti. Res. Hoardsan. 31(2), $238-234$.

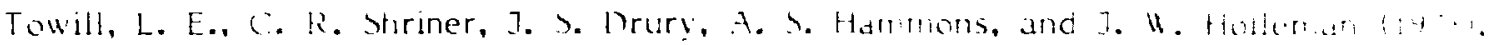

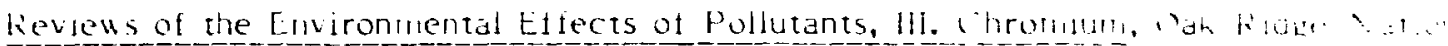

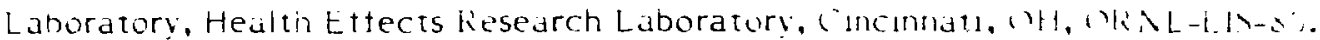

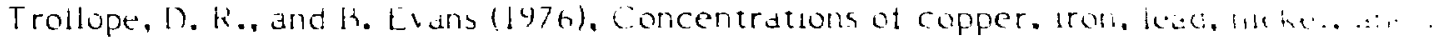
In treshuater algial blooms, Environ. Pollut. $7(2), 104-116$.

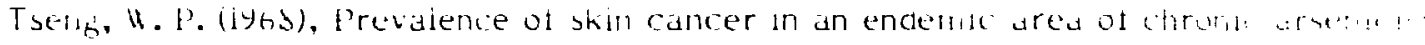
Taman, J. Nat. Cancer Inst. 40.433.

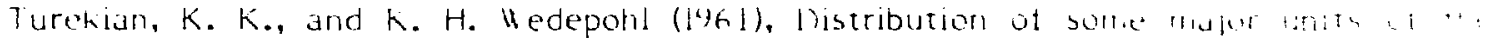
Larth's crust, creol. soc. ․m. Hull. 22, 175-192.

linderuood, E. N. (1971), Trace Elements in Human and Animal Xutritull $\quad \therefore \quad \therefore, \ldots$ l'ress, ven lorki), 3rded.

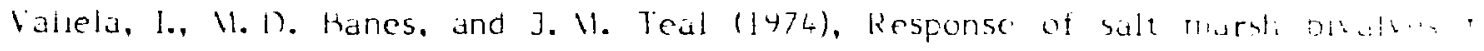
enrichment with metal-contianing sewage sludge and retention of lead. $\therefore$ l:a cadmium by marsh sediments, Environ. Pollut. 7(2), 149-157.

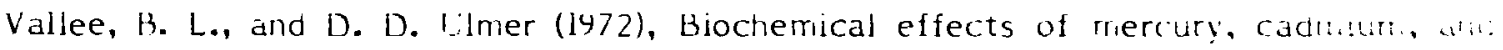
lead, Annu. Rev. Biochem. 41, 91-128.

Wagemann, R. (1979), Some theoretical aspects of stability ana solubility of inorkulii arsenic in the freshuater exvironment, Water kes. 12(3), 139-145.

Warren, H. V. (1974), Environmental lead: a survey of its possible physiologlcul signiticance, ]. Biosocial. 3 c1. 6(2), 223-238. 
Waslenchuk, D. G., and H. L. Windom (1978), Factors controlling the estuarine chemistry of arsenic, Estuarine Coastal Mar. Sci. 7(5), 455-464.

Waslenchuk, D. G. (1979), The geochemical controls on arsenic concentrations in Southeastern I.Inited States rivers, Chem. Geol. 24 3 , 3i5-325.

Watters, K., D. N. Edgington, T. E. Hakonson, W. C. Hanson, W. H. Srnith, F. W. Whicker, and R. E. Wildung (1980), synthesis of the research literature, in Iransuranic Elements in the Environment, w. C. Hanson, Ed., Department of Energy, Technical Information Center, $H$ ashington, $D C$.

Eook, B. C. (1978), Lead intoxication in urban dogs, in Toxicity of Heavy Mletals in the Environment. F. W. Dehmie, Ed. (Marcel Dekker Inc., New York), part 1, Pp. 179-190. 